\title{
Twenty odd years of stretch-sensitive channels
}

\author{
O. P. Hamill
}

Received: 14 June 2006 / Accepted: 27 June 2006 / Published online: 21 September 2006

(C) Springer-Verlag 2006

\begin{abstract}
After formation of the giga-seal, the membrane patch can be stimulated by hydrostatic or osmotic pressure gradients applied across the patch. This feature led to the discovery of stretch-sensitive or mechanosensitive (MS) channels, which are now known to be ubiquitously expressed in cells representative of all the living kingdoms. In addition to mechanosensation, MS channels have been implicated in many basic cell functions, including regulation of cell volume, shape, and motility. The successful cloning, overexpression, and crystallization of bacterial MS channel proteins combined with patch clamp and modeling studies have provided atomic insight into the working of these nanomachines. In particular, studies of MS channels have revealed new understanding of how the lipid bilayer modulates membrane protein function. Three major membrane protein families, transient receptor potential, 2 pore domain $\mathrm{K}^{+}$, and the epithelial $\mathrm{Na}^{+}$channels, have been shown to form MS channels in animal cells, and their polymodal activation embrace fields far beyond mechanosensitivity. The discovery of new drugs highly selective for MS channels ("mechanopharmaceutics") and the demonstration of MS channel involvement in several major human diseases ("mechanochannelopathies") provide added motivation for devising new techniques and approaches for studying MS channels.
\end{abstract}

Keywords Mechanosensitive channels .

Mechanotransduction · Transient receptor potential .

Patch clamp · Giga seal

O. P. Hamill $(\bowtie)$

Neurosciences and Cell Biology, UTMB,

Galveston, TX 77555, USA

e-mail: ohamill@utmb.edu

\section{Introduction}

The formation of the giga-seal depends upon applying suction to draw the membrane into the pipette. Once the seal is formed, suction is not necessary, and it should be released [53]. However, the membrane patch spanning the pipette can now be mechanically stimulated by hydrostatic or osmotic pressure gradients applied across the patch without disrupting the seal. This feature allowed the first recordings of cell-swelling and stretch-activated channel currents $[50,52]$. Over the last 20-odd years, interest in mechanosensitive (MS) channels has progressed from being a possible patch clamp recording artifact to a central player in our understanding of protein-bilayer interactions and a promising new therapeutic target against several major human diseases. This article highlights some recent developments and unresolved issues regarding MS channels, with a major focus on the MS $\mathrm{Ca}^{2+}$ permeant cation channel (MscCa) recently identified in vertebrate cells [97].

What happens to the membrane patch in the pipette?

An important issue for MS channels is how the process of aspiration and sealing of the membrane in the pipette alters the mechanics and possible stretch sensitivity of channels in the patch. Because of the small size and inaccessibility of the patch in the pipette, a variety of techniques, including high-resolution video imaging [121, 152-154, 184], high-voltage electron microscopy [142], atomic force microscopy [70], and fluorescence-imaged microdeformation $[32,33]$ have been used to study the aspirated patch and its underlying cell cytoskeleton (CSK). Here we focus on results obtained on the Xenopus oocyte [182-185]. The first issue is whether the pressure/ suction applied to the patch after seal formation somehow 
induces changes in the seal resistance that appear as "MSchannel-like" events. This idea is not entirely far-fetched because video imaging indicates that suction tends to peal the membrane off the walls of the pipette [121], and gated, cation-selective channels have been recorded with patch pipettes sealed onto noncellular hydrophobic surfaces [145]. However, although strong suction can rupture the patch, it typically does not disrupt the giga-seal, thereby allowing for tight seal whole-cell and/or outside-out patch recording [53]. In addition, suction ramps applied to cell-attached frog oocyte patches reversibly activate either a saturating macroscopic current (Fig. 1a) or a unitary amplitude current event (Fig. 1b) depending upon patch area [60]. These current waveforms are consistent with multiple and single MS channel patches, respectively, but difficult to reconcile with MS changes in seal resistance. Even more compelling is that patches formed on pure liposomes fail to express MS channel currents $[97,102,122,160]$. This absence allowed for the identification of MS channel proteins following functional reconstitution of solubilized membrane proteins from bacteria and archaea $[81,158,159]$ and, most recently, from Xenopus oocytes [97].

Although MS channels are clearly not seal "leaks," the sealing process does change patch geometry and the underlying CSK, thereby altering patch mechanics. For example, Fig. 2a and b shows electron microscopy (EM)
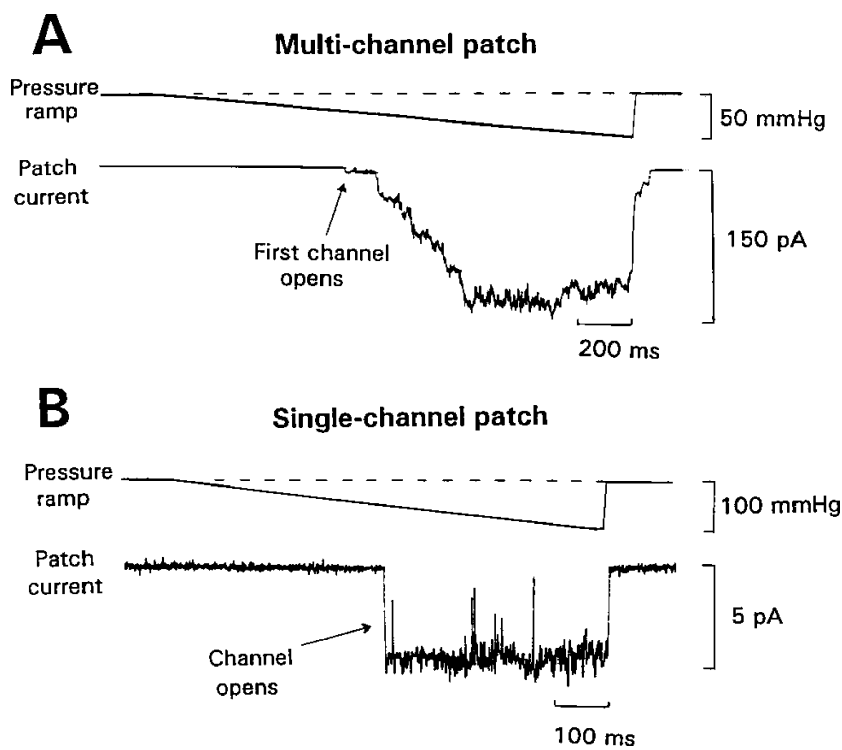

Fig. 1 Ramps of suction applied to two different-size patches formed on a Xenopus oocyte are consistent with a finite number of discrete MS channels but inconsistent with pressure-induced leaks in the seal. a A relatively large patch formed with an approximately $3-\mu \mathrm{m}$ diameter tip pipette shows a current that fully saturates at around $40 \mathrm{mmHg}$. The arrow indicates the initial opening of $5 \mathrm{pA}$ single $\mathrm{MscCa}$. b A smaller patch formed with an approximately $0.50-\mu \mathrm{m}-$ diameter tip pipette reveals the opening of single $\mathrm{MscCa}$, indicating that once open, the channel current was independent of suction. These results indicate that $\mathrm{MscCa}$ is either open or closed, and the saturation of current in a multichannel patch represents the balance between opening and closing rates for a finite number of channels images of the Xenopus oocyte surface, indicating its extensive membrane folding and high density of microvilli (est. $\sim 7$ microvilli per square micrometer) $[181,184,185]$. This complex membrane geometry is also reflected in electrical capacitance $\left(C_{\mathrm{m}}\right)$ measurements that indicate a membrane surface area that is tenfold greater than that required for the cell's volume [184]. In contrast, highresolution video images of cell-attached oocyte patches (Fig. 2c, d) indicate an optically smooth membrane that is pulled flat and perpendicular to the walls of the pipette $[184$; see also $113,152,153,161]$. Furthermore, $C_{\mathrm{m}}$ measurements indicate a patch area of approximately $50 \mu \mathrm{m}^{2}$, consistent with the patch geometry but inconsistent with the approximately $500 \mu \mathrm{m}^{2}$ expected if the approximately 300 microvilli and membrane folds evident in Fig. $2 \mathrm{a}$ and $\mathrm{b}$ were preserved during the sealing process [184]. Presumably, the suction used to obtain the giga-seal is sufficient to smooth out the surface folds and microvilli so that the cell membrane is now tightly stretched over an expanded CSK (Fig. 3). This smoothing out of microvilli is not an exclusive patch clamp phenomenon because a similar phenomenon has been visualized in EM studies of cells undergoing osmotic inflation [82] and spreading before cell migration [37]. In these cases, the process is presumably reversible, indicating the considerable plasticity of the microvilli and their supporting CSK.

There are at least two related mechanisms by which changes in patch geometry will increase stretch sensitivity of channels in the patch. First, in the absence of any excess membrane, brief pressure pulses applied to the patch will rapidly flex the membrane and increase bilayer tension (Fig. 2c, d). The flexing of the membrane either outward with suction or inward with pressure results in the rapid activation $(<1 \mathrm{~ms})$ of inward channel currents $[107,108$, 184]. In contrast, more sustained pressures would be required to inflate the oocyte and smooth out the membrane reserves to increase membrane tension $\left(T_{\mathrm{m}}\right)[15,117,184]$. Second, according to Laplace's law, $P=2 T_{\mathrm{m}} / r$, the pressure $(P)$ required to activate channels in the patch with a radius of curvature $(r)$ of approximately $1 \mu \mathrm{m}$ would be $1 / 20$ th of that required to activate the same channels located on microvilli that have a radii of curvature of approximately $0.05 \mu \mathrm{m}$. For example, stimulus-peak current relations shown in Fig. 4 indicate that half the channels in an oocyte patch are activated by a suction of approximately $10 \mathrm{mmHg}$ $\left(\sim 1.3 \mathrm{kN} \mathrm{m}^{-2}\right)$, which translates to a tension of approximately $0.6 \mathrm{mN} \mathrm{m}^{-1}$ (i.e., the near-symmetrical suction/ pressure relations indicate a tension-gated channel and justify Laplace's law). To achieve the same tension in microvilli would require a suction of $200 \mathrm{mmHg}$. However, this would exceed the approximately $100-\mathrm{mmHg}$ that causes patch rupture (i.e., a lytic tension of $\sim 6 \mathrm{mN} \mathrm{m}^{-1}$ ) under these conditions [119]. 
Fig. 2 Comparison of the membrane geometry of the oocyte surface and of the patch sealed in a pipette. a Transmission EM of the oocyte surface showing prominent microvilli containing dark cytoplasmic material. b Scanning EM of the oocyte surface, indicating the high density of microvilli. c High-resolution video images of a membrane patch before (0 $\mathrm{ms})$, during $(50 \mathrm{~ms})$, and after (250 ms) a 100 -ms suction step. d The same patch as in $C$ except a 100-ms pressure step was applied. Both suction and pressure steps activated a $50-\mathrm{pA}$ inward current (modified from Zhang and Hamill [184] and Zhang et al. [185] with permission)
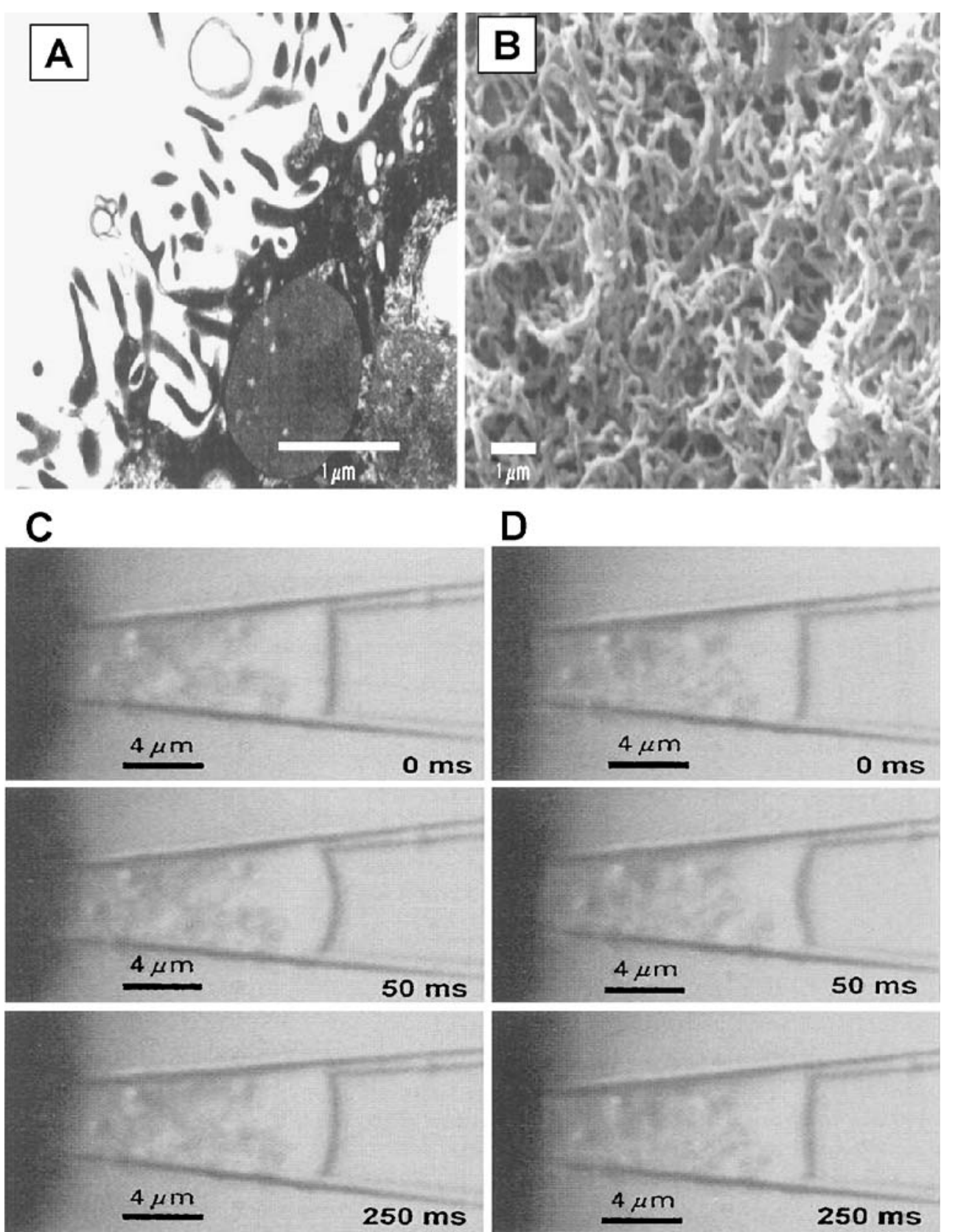

The sealing process may also alter patch mechanics by changing the CSK structure underlying the patch $[55,63$, 173]. When a gentle sealing protocol is used to achieve the giga-seal, the cortical CSK network that is pulled into the pipette may be dilated without disrupting its links with the membrane [54, 185; see also 32, 33]. However, if the suction used to draw the membrane into the pipette exceeds the strength of CSK-membrane linkages, then a CSK-free membrane (bleb) may be formed [55, 63, 112]. Similarly, after the membrane has sealed in the pipette, additional suction may cause the blebbing at the membrane cap as shown in Fig. 5 [185]. This membrane blebbing can either increase or decrease the stretch sensitivity depending upon the specific MS channel. For example, the TREK and TRAAK MscK channels show an increase in stretch sensitivity, presumably because the CSK normally acts as a constraint and prevents tension being conveyed to the bilayer $[69,151]$. On the other hand, MscCa typically shows a loss of both stretch sensitivity and fast dynamics presumably because they depend upon CSK interactions with the channel/membrane (Fig. 5) [55, 156, 185].

In summary, giga-seal formation introduces significant changes in patch mechanics that can alter the mechanosensitivity of channels in the patch. The extrinsic changes in membrane geometry and CSK structure may have different effects on specific channels depending upon 


\section{PIPETTE}
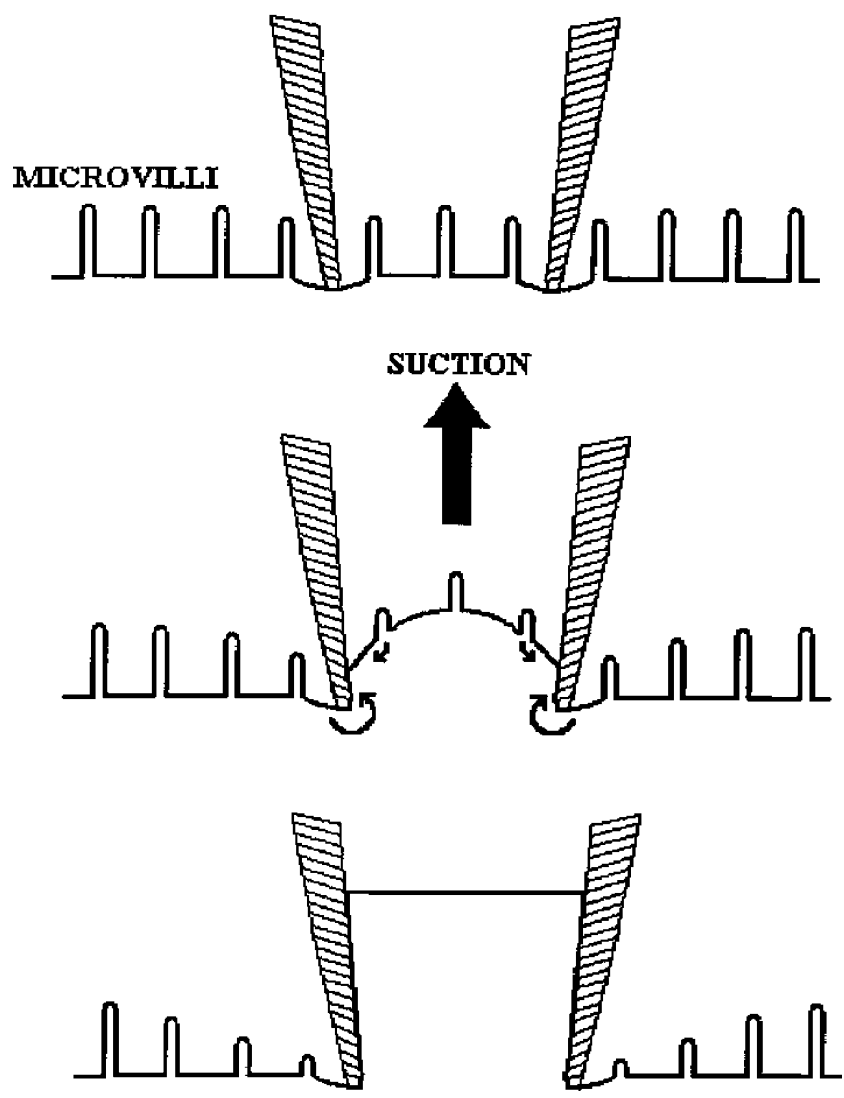

Fig. 3 Schematic illustrating the proposed smoothing out of microvilli caused by the pipette aspiration and giga-seal formation

their intrinsic properties (i.e., protein structure and proteinCSK interactions).

Do animal cells generate/experience membrane tensions that activate MS channels?

Although it has been questioned whether animal cells experience the same in-plane membrane tensions that activate MS channels in the patch [30, 149, 172], there is evidence that they can experience even larger tensions that result in membrane rupture. In particular, cell wounding events, as judged by the cell filling with the membrane impermeant fluorescein-labeled dextran, have been observed in experimentally unperturbed rodent skin, gut epithelium, cardiac, and skeletal muscle, and found to increase in frequency with mechanical loading [11, 109111, 164]. The cell types that commonly experience wounding in vivo include epidermal cells and fibroblasts (skin), epithelial cells and smooth muscle (GI tract and respiratory system) endothelial cells, and smooth muscle (cardiovascular system) and peripheral neurons. The proportion of the cells wounded in the various systems can range from 2 to as high as $25 \%$. In eccentrically exercised muscle (e.g., downhill running), there can be a tenfold increase in cell wounding compared with resting muscle, and in dystrophic mice that lack the CSK-structural protein dystrophin, exercise can produce massive wounding events that ultimately overload the muscle regeneration mechanisms [180]. Normal migrating cells can generate traction forces that not only lengthen and stretch the cell but also cause cell fragments to be ripped off and deposited along the migration trail [104]. Furthermore, if the normal contractile mechanisms that allow a migrating cell to retract its rear are blocked, the front of the cell can tear away from the cell body and move off as a motile cell fragment [170]. The common occurrence of these traumatic mechanical stresses under physiological and pathological conditions has presumably provided strong selective pressure for the evolution of the membrane resealing mechanism(s) that is widely expressed in eukaryotic cells [11, 109-111, 164].

Despite the above evidence of membrane rupture tensions (i.e., $>5 \mathrm{mN} \mathrm{m}^{-1}$ ), direct estimates of membrane tension in "resting" isolated cells indicate much lower values $\left(<0.1 \mathrm{mN} \mathrm{m}^{-1}\right)[28-31,116,138]$. The tension measurement involves pulling a tether from the cell surface using optical tweezers and measuring the force required to maintain it at constant length. The basic assumption is that membrane tension is contiguous over the whole surface so that pulling a tether from one region perturbs the tension in all regions of the cell membrane. From the static tether force $\left(F_{0}\right)$ measured in piconewtons, one can estimate the membrane tension $T_{\mathrm{m}}$ according to the equation:

$F_{0}=2 \pi\left(2 B T_{m}\right)^{1 / 2}$

where the membrane bending stiffness $(B)$ is assumed to be constant with a value of $2.7 \times 10^{-19} \mathrm{~N} \mathrm{~m}^{-1}$. The practical limitation of this technique is that the optical tweezers can only sustain forces up to $100 \mathrm{pN}$, which would correspond to a tension of $0.5 \mathrm{mN} \mathrm{m}^{-1}$. For an animal cell with its cortical CSK, the measured tension is assumed to represent a combination of in-plane tension and CSK adhesion, and is referred to as the "apparent" tension. However, $T_{\mathrm{m}}$ measurements of membrane blebs that lack CSK indicate the in-plane tension contributes only $25 \%$ of the $T_{\mathrm{m}}$ value [28]. Experiments on two different cell types (RBL 2H3 cells and snail neurons) indicate that cell swelling increases steady-state tensions from approximately 0.04 to 0.12 $\mathrm{mN} \mathrm{m}{ }^{-1}$, which then returns to approximately 0.04 $\mathrm{mN} \mathrm{m}^{-1}$ with reshrinking [30, 31]. However, the same cells also experience tension surges that exceed the strength of the trap (i.e., $>0.5 \mathrm{mN} \mathrm{m}^{-1}$ ). Based on other experiments measuring exocytosis/endocytosis as a function of membrane tension, it has been proposed that membrane surface area and tension are in a feedback loop in which high tensions favor membrane recruitment, and low tension favors membrane retrieval $[31,116,148]$. As a conse- 
Fig. 4 Inward current responses to suction and pressure pulses applied to an oocyte patch. a Both suction and pressure pulses $(2.5 \mathrm{~s})$ result in rapid opening of MscCa that mostly close within $200 \mathrm{~ms}$ of the pulse. b Schematic showing flexion of the patch outward (suction) or inward (pressure) c Stimulus-response relations for suction and pressure steps. The sigmoid fits indicate that suction $\left(P_{0.5}=-10 \mathrm{mmHg}\right)$ was slightly more effective than pressure $\left(P_{0.5}=14 \mathrm{mmHg}\right)$ in activating $\mathrm{MscCa}$

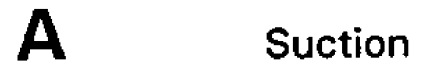

Pressure
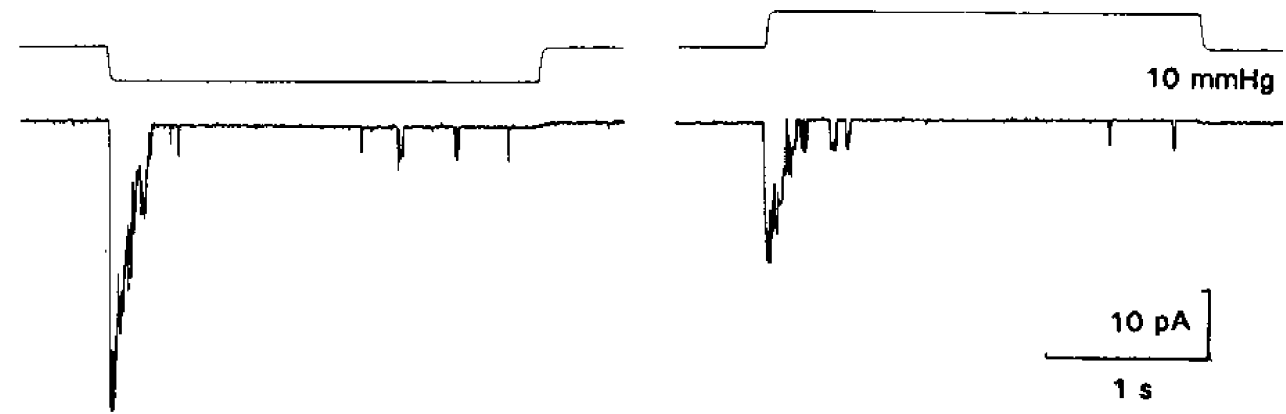

B

Suction

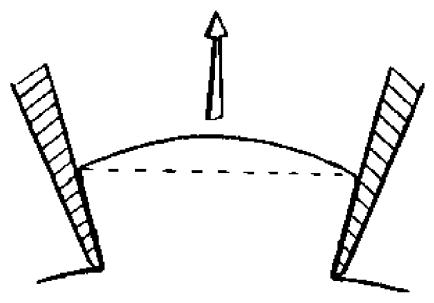

Pressure

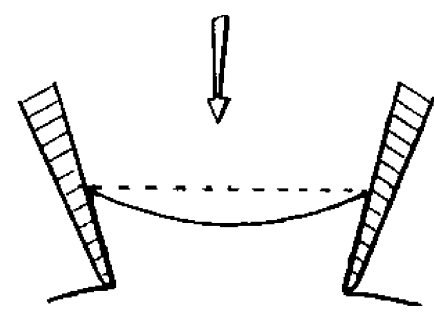

C

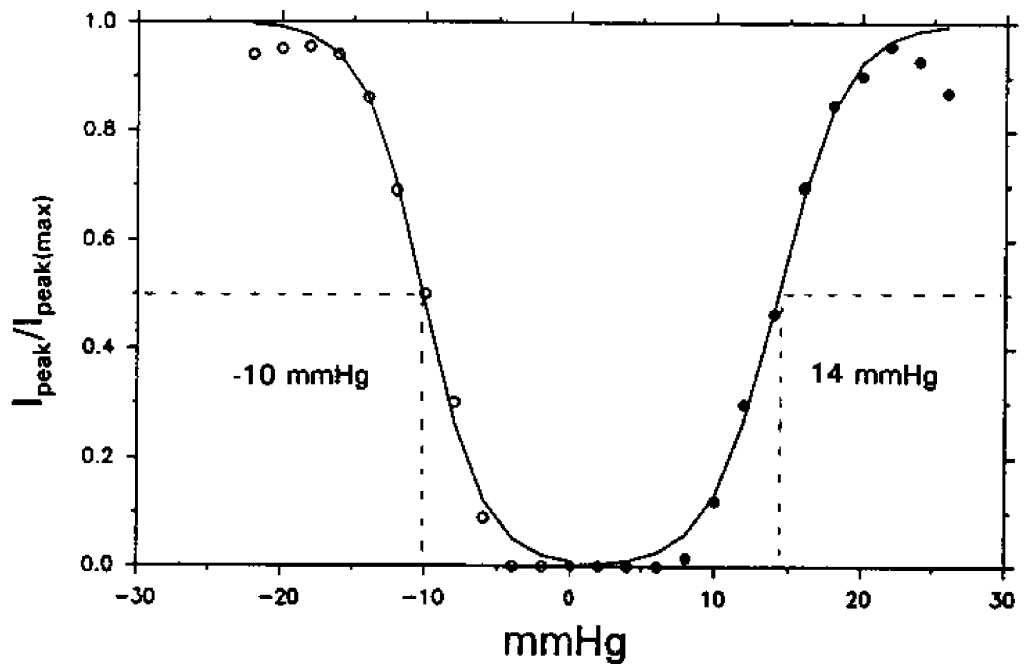

quence, it has been proposed that surface area regulation (SAR) maintains membrane tension around a relatively low set point of approximately $0.1 \mathrm{mN} \mathrm{m}^{-1}$, which would be well below the lytic tension $\left(\geq 5 \mathrm{mN} \mathrm{m}^{-1}\right)$ and the near-lytic tensions $\left(\sim 4 \mathrm{mN} \mathrm{m}^{-1}\right)$ required to activate the bacterial MS channels. However, the direct measurement of high tension surges exceeding the low set point and the occurrence of cell wounding events indicate that SAR mechanisms can be saturated. Furthermore, as indicated in Fig. 6, lower tensions are required to activate MS channels in animals cells $\left(T_{50 \%}\right.$ for $\left.\mathrm{MscK}=2.4 \mathrm{mN} \mathrm{m}^{-1}\right)$ and $(\mathrm{MscCa} \sim 0.6$

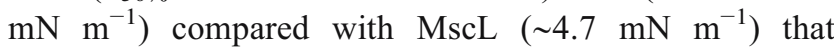
functions as a last-resort safety valve [94]. As a conse- quence, MS channels in animal cells would seem more geared to regulating processes with lower tension set points such as regulatory volume decrease [20, 26, 146, 147, 169] cell locomotion [92] and, possibly, SAR via $\mathrm{Ca}^{2+}$-induced exocytosis. However, it appears that integrins rather than $\mathrm{MscCa}$ act as the mechanosensor for MS exocytosis/ membrane trafficking at the frog neuromuscular junction [24] and the oocyte [96].

"Mechanopharmaceutics"

Progress in the MS channel field would be greatly enhanced by the discovery of high-affinity agents that 


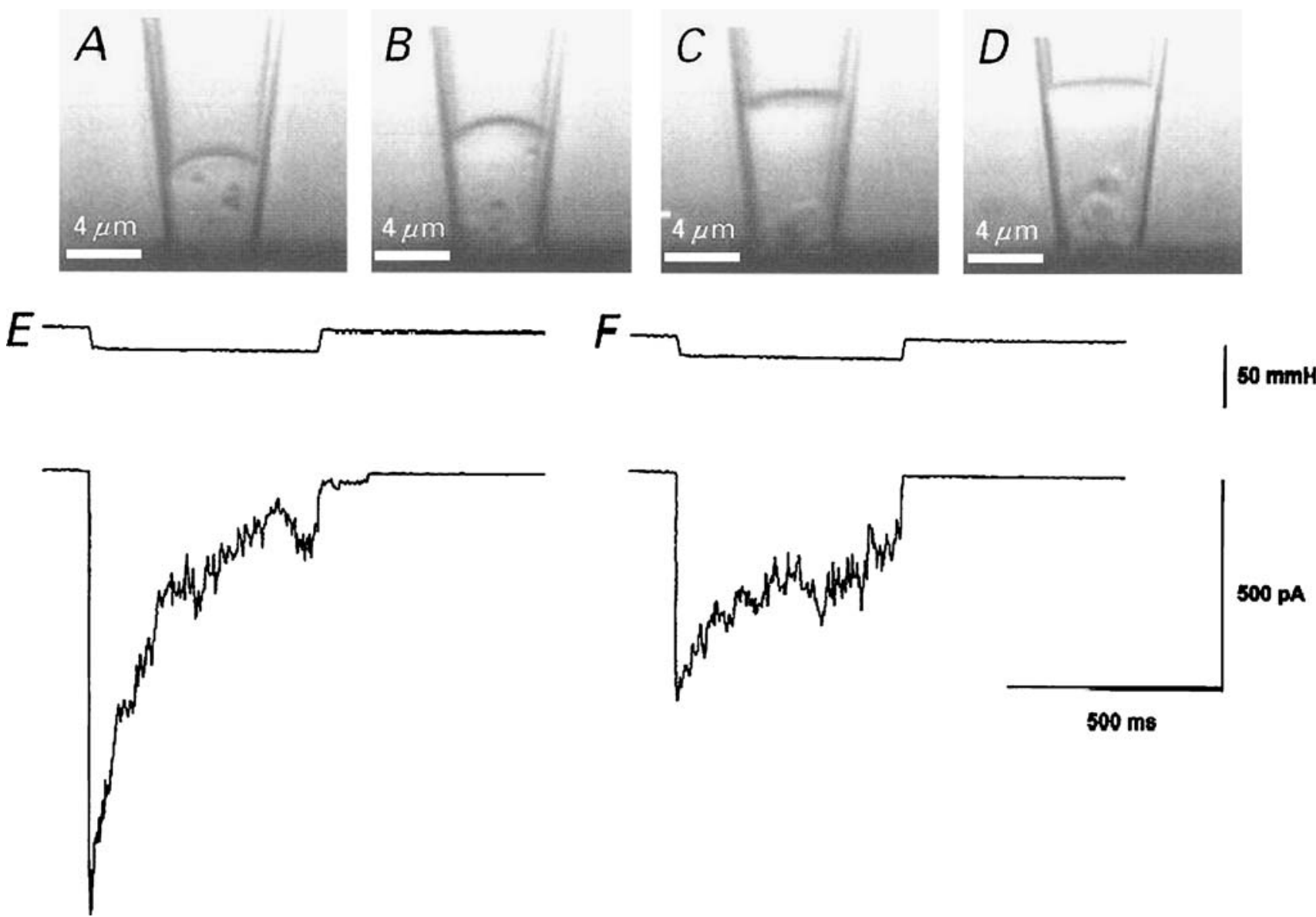

Fig. 5 Changes in the membrane and patch currents as a consequence of repetitive pressure pulses applied to the patch pipette. $\mathbf{a}-\mathbf{d}$ video images of a cell-attached patch at different times after formation of the giga-seal. Between each image, suction steps $(20 \mathrm{mmHg}, 500 \mathrm{~ms})$ were applied. a The first image taken immediately after giga-seal formation shows the patch curved outwards and located closed to the end of the pipette $(\sim 5 \mu \mathrm{m})$. Particles located in the cytoplasm exhibited no motion presumably because they were still constrained by the intact CSK. b-d repetitive suction pulse caused the patch to

selectivity target specific MS channels. These agents would be highly useful for following MS channel proteins during purification procedures and identifying MS channel roles in novel functions. In addition, given that MS channels may be polymodally activated (e.g., by tension, voltage, $\mathrm{pH}$, temperature, $\mathrm{Ca}^{2+}$ store depletion, and/or lipid second messenger) [27, 125, 171], it would be advantageous to discover agents that selectively acted on MS channel only when they were mechano-gated. Although no ideal MS channel reagent has yet been discovered, a number of compounds have been identified that act as MS channel blockers or activators $[48,61,65]$. One class, amiloride and its analogs, appear to act on a traditional "lock and key" protein receptor, whereas other agents, GsMTx-4 and possibly maitotoxin, seem to act via nontraditional "receptors" at the lipid or lipid-protein interface where they may move up the pipette away from the cell, and a clear space developed between the membrane and the CSK remaining close to the cell. Particles that moved into this space displayed Brownian motion, indicating the loss of constraining CSK structures [153]. e Application of suction pulses at a caused a rapid opening of $\mathrm{MscCa}$ that closed almost completely. f Application of a suction pulse at $\mathbf{d}$ caused activation of a smaller more sustained current (from Zhang et al. [185] with permission)

change the local bilayer mechanics and thereby modify MS channel gating. Below we briefly review their salient features.

Amiloride has been the most rigorously studied in terms of its MS channel blocking mechanism and provides an example where variations in mechanistic detail may enable discrimination between different channel families in terms of their participation in specific MS functions. In particular, the amiloride block of MscCa/TRPC-1 in Xenopus oocytes [56, 89-91] and $\mathrm{MscCa}$ in vertebrate hair cells [141] has been shown to involve basically the same unusual mechanism in which two amiloride molecules bind cooperatively to channel sites that only become accessible at hyperpolarized potentials after the channel has opened. This mechanism, referred to as "conformational" block, implies different open-state conformations at hyperpolarized vs 


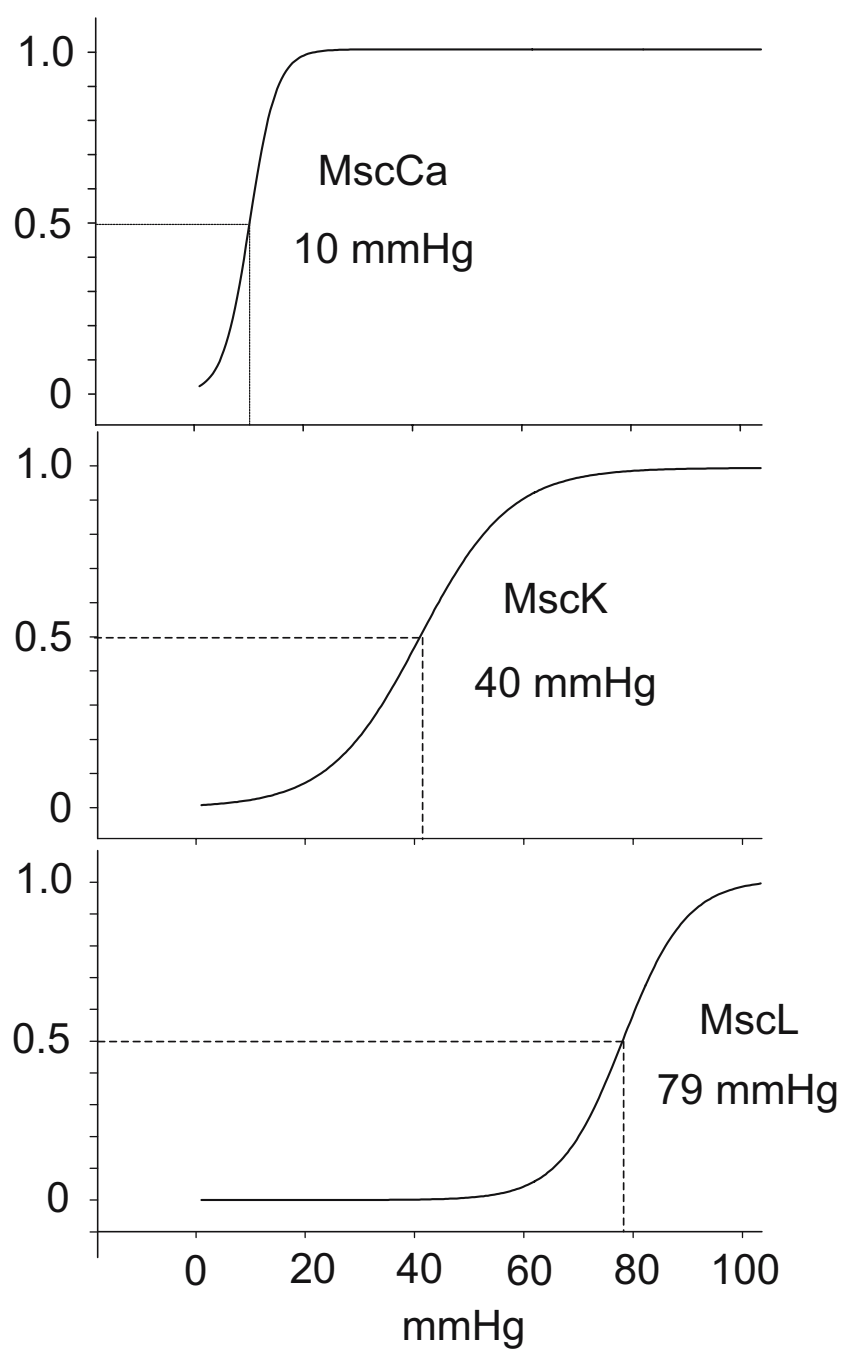

Fig. 6 Comparison of the normalized pressure-current relations for three different MS channels. MscCa curve fitted to curve Fig. 2c (top). MscK curve fitted to data from Ref. [69] (middle). MscL curve fitted to data from Ref. [54] (bottom)

depolarized potentials, and is distinctly different from the amiloride block of the high-affinity amiloride-sensitive epithelial $\mathrm{Na}^{+}$channel $(\mathrm{ENaC})$ where the voltage dependency arises because the positively charged amiloride binds to a pore site that senses a fraction of the electric field [130]. A further difference is seen in the order of potencies of amiloride analogs in blocking the two channel classes (Table 1) [80]. Amiloride blocks the MEC-4 DEG/ENaC currents in touch receptor neurons in Caenorhabditis elegans [120] and also the mammalian arterial myogenic response, which has been used to implicate DEG/ENaC as the vascular mechanosensor [34]. However, amiloride also blocks TRPC-6, also implicated as the arterial smooth muscle mechanosensor [74, 175]. It will be interesting to determine if mechanistic differences in amiloride block (i.e., conformational vs pore block) can be used to resolve the MS Channel's identity.

Gadolinium blocks a variety of MS channels (e.g., MscCa, MscK, MscL, and MscS), several TRP channels (e.g., TRPC-1, TRPC-4, TRPC-5, and TRPV1), various voltage-gated $\left(\mathrm{Ca}^{2+}, \mathrm{Na}^{+}\right.$, and $\left.\mathrm{K}^{+}\right)$and receptor-gated channels [e.g., $N$-methyl D-aspartate (NMDA), AChR, etc.] [61, 124, 136, 144, 165, 176, 178]. Because of its trivalency, $\mathrm{Gd}^{3+}$ will bind with high affinity to negative groups on proteins, lipids, and polysaccharides, as well as any inorganic anions present in solution $[17,61]$. Its ionic radius $(0.938 \AA)$, which is similar to $\mathrm{Na}^{+}(0.97 \AA)$ and $\mathrm{Ca}^{2+}$ $(0.99 \AA)$, may also allow it to enter and bind to negatively change groups (Glu and/or Asp) within cation channels. Evidence that $\mathrm{Gd}^{3+}$ interacts directly with channel proteins comes from studies of specific TRP members (TRPV-1, TRPC-4, and TRPC-5) where $\mathrm{Gd}^{3+}$ has been shown to have dual effects, activating the channels at low micromolar concentrations $(<100 \mu \mathrm{M})$ but blocking at higher concentrations $(>300 \mu \mathrm{M})$. The activation of TRPV-1 depends upon binding to specific external glutamate residues that confer acid sensitivity on the channel, and neutralization of these residues blocks the activation and modifies inhibition [165]. Similar concentration-dependent potentiating and blocking effects also occur with TRPC-4 and TRPC-5 [77]. In contrast, $\mathrm{Gd}^{3+}$ only blocks TRPC-1 and TRPC-3 channels at relatively low micromolar concentrations [97, 166].

Table 1 Amiloride analog potency $\left(\mathrm{IC}_{50}\right.$ amiloride/ $\mathrm{IC}_{50}$ analog) of $\mathrm{MS}$ channels and the epithelial $\mathrm{Na}^{+}$channel

\begin{tabular}{|c|c|c|c|c|c|c|c|c|}
\hline & $\begin{array}{l}\text { Amiloride } \\
(\mathrm{IC} 50, \mu \mathrm{M})\end{array}$ & DMA & Phenamil & PBDCB & Benzamil & HMA & I-NMBA & Reference no. \\
\hline MscCa mouse hair cell & $1(53)$ & 1.3 & 4.4 & 5 & 9.6 & 12.3 & 29 & {$[141]$} \\
\hline MscCa Xenopus oocyte & $1(500)$ & 1.4 & - & - & 5.3 & 14.7 (BrHMA) & & {$[90]$} \\
\hline $\begin{array}{l}\text { Epithelial } \mathrm{Na}^{+} \text {channel } \\
\text { (high affinity) }\end{array}$ & $1(0.34)$ & 0.04 & 17 & - & 9 & 0.04 & 7 & {$[80]$} \\
\hline $\begin{array}{l}\text { Epithelial } \mathrm{Na}^{+} \text {channel } \\
\text { (low affinity) }\end{array}$ & $1(10)$ & 2.2 & 2.9 & - & 3.8 & - & - & {$[80]$} \\
\hline
\end{tabular}

$D M A$ Dimethylamiloride; $P B D C B$ 5-( $N$-propyl- $N$-butyl)-dichlorobenzamile; $H M A$ hexamethyleneamiloride; $I-N M B A$ 6-iodide-2-methoxy-5nitrobenzamile; $B r H M A$ bromohexamethylene amiloride 
An early view on how $\mathrm{Gd}^{3+}$ might block MS channels was via effects on the bilayer. $\mathrm{Gd}^{3+}$ has been shown to interact with black lipid membranes containing the negatively charged phosphatidylserine (PS) but not with the neutral phosphatidylcholine to increase the boundary potential and membrane tension [38]. However, whether these effects underlie MS channel block remains unclear because PS is normally restricted to the internal-facing monolayer, and $\mathrm{Gd}^{3+}$ acts externally. $\mathrm{Gd}^{3+}$ has also been shown to promote shape changes in giant unilamellar vesicles lacking PS [162]. In this case, it was proposed that $\mathrm{Gd}^{3+}$ bound to the hydrophilic lipid head (i.e., negative charge of the phosphate groups) of the external monolayer, and in doing so, decreased its surface area relative to the internal monolayer, thereby causing a change in membrane curvature. However, whether this effect would block MS channels remains unclear because amphipaths that also change membrane curvature usually result in MS channel activation [101, 135]. A recent study has reported that $\mathrm{Gd}^{3+}$ can block MS channels without altering pressure-induced changes in $C_{\mathrm{m}}$, which would be expected if $\mathrm{Gd}^{3+}$ acted by altering membrane mechanics [156]. However, as pointed out by the authors, measurement of this parameter may be complicated because $\mathrm{Gd}^{3+}$ has multiple effects, including increasing the giga-seal [35].

GsMTx-4 is a 34 -amino acid (4 $\mathrm{kDa})$ peptide isolated from tarantula venom $[48,49,155,157]$. It is amphipathic with a hydrophobic membrane face opposite a positively charged face, and it is a member of the inhibitory cysteine knot (ICK) toxin superfamily. GsMTx-4 is the most specific MS blocker identified to date. Because of its structure, it would be expected to be attracted to negative regions of proteins/lipids, and it will tend to partition into hydrophobic pockets either within the protein or at the protein/lipid interface. Unlike the nonspecific channel blocker $\mathrm{Gd}^{3+}$, GsMTx-4 has so far not been reported to affect voltage- or receptor-gated channel. GsMTx-4 blocks MscCa at between 0.2 and $3 \mu \mathrm{M}$ in chick heart, rat astrocyte, and human bladder and kidney cells [48, 49], and the crude tarantula venom also blocks $\mathrm{MscCa}$ in growing pollen protoplasts [36]. Most recently, GsMTx-4 has been shown to stimulate neurite outgrowth by blocking $\mathrm{Ca}^{2+}$ elevation in Xenopus spinal neurons [76]. However, GsMTx-4 does not block $\mathrm{MscCa}$ involved in auditory transduction [48], MscK formed by TREK (E. Honore, unpublished observations, cited in Ref. [48]) the bacterial MscL [99], and perhaps, most surprisingly, MscCa in Xenopus oocytes (R. Maroto and O.P. Hamill, unpublished observations). The last result is puzzling given that the oocyte $\mathrm{MscCa}$ is often treated as the prototypical $\mathrm{MscCa}$, and TRPC-1 has been implicated as forming MscCa in the Xenopus oocyte and mammalian cells [97]. One possible explanation is that there are structural differences between $\mathrm{MscCa}$ proteins in different cell types. However, based on the observation that GsMTx-4 synthesized from $\mathrm{D}$ instead of $\mathrm{L}$ amino acids shows the same potency in blocking specific MS channels, it has been proposed that GsMTx-4 is more likely to act by binding to boundary lipids surrounding the channel, and, at least, consistent with this is that GsMTx-4 and its enantomer also alters the gating of gramicidin A, which is particularly sensitive to bilayer mechanics [157]. It may therefore be that differences in lipids between poikilotherms vs homeotherms is a factor that underlies the different GsMTx-4 sensitivities. In this case, it will be particularly interesting to determine GsMTx-4 action on MscCa/TRPCs reconstituted into defined lipid environments.

Maitotoxin (MTX) is a highly potent marine poison (LD 50 for mice $50 \mathrm{ng} / \mathrm{kg}$ ) from the dinoflagellate (Gambierdiscus toxicus) that is responsible for Giguartera, a form of seafood poisoning [40]. It is water-soluble polyether with 2 sulfate esters, 28 hydroxyls, and 32 ether rings, and with a molecular weight of $3.4 \mathrm{kDa}$, it is the largest among the known nonbiopolymers. The hydroxyl and ionized sulfate groups makes MTX a highly polar substance, but the presence of large hydrophobic portions make it amphipathic so that it most likely inserts itself deep into the bilayer. MTX elicits $\mathrm{Ca}^{2+}$ influx in a variety of cell types, and the $\mathrm{Ca}^{2+}$ influx may lead to secondary effects, including phosphinositide breakdown and arachidonic release. Of special interest here in that cells expressing TRPC-1 show a substantial increase in MTXinitiated $\mathrm{Ca}^{2+}$ influx that is blocked by $\mathrm{Gd}^{3+}\left(K_{\mathrm{D} 50}=3 \mu \mathrm{M}\right)$ and also by amiloride and benzamil but not by flufenamic acid or niflumic acid [10, 14, 174]. MTX activates $40 \mathrm{pS}$ channels when applied to outside-out patches but not inside-out patches indicate that MTX acts on the extracellular face and does not require second messengers [40]. Both the conductance and pharmacological properties have led to the idea that MTX activates the $\mathrm{MscCa}$ channels in oocytes, which is consistent with its effect of activating similar channel currents in TRPC-1 expressing cells. On the other hand, MTX also increases $\mathrm{Ca}^{2+}$ influx in red blood cell (RBC) ghosts which may involve another mechanism [85]. Although it has been suggested that MTX mainly acts to increase current by stimulating insertion of channels in the oocyte membrane, the evidence is based on large rapid $C_{\mathrm{m}}$ changes that follow moment-to-moment changes in conductance induced by MTX and which are blocked by the same ions and agents that also block the conductance changes [174]. These properties indicate the $C_{\mathrm{m}}$ changes may have been contaminated by changes in membrane conductance [25]. In this case, alternative methods for measuring membrane trafficking (e.g., FMI-43 fluorescence) should be used to test whether MTX-induced 
membrane conductance occurs by channel insertion and/ or channel activation [40].

Mechanosensitive channel protein identification

The membrane proteins forming specific MS channels have only been recently identified, and there were several reasons for this delay, including the general low abundance of MS channels in animal cells, the absence of high-affinity MS channel agents, the inability to employ conventional expression cloning strategies because of widespread endogenous MS channel expression, and the absence of identified mutant phenotypes involving stretch-activated channels. To overcome these handicaps, a novel strategy was developed by Sukharev et al. [159, 160] that involved detergent-solubilizing and fractionating membrane proteins, reconstituting the protein fractions in liposomes, then assaying the fractions for stretch sensitivity using patch clamp recording. This technique has been used to identify a variety of MS channel proteins in bacteria and archaea [81, 103, 158, 159] and, most recently, the TRPC protein family in forming $\mathrm{MscCa}$ in Xenopus oocytes [97]. Furthermore, by demonstrating that a purified protein reconstituted in pure liposomes can retain stretch sensitivity, the technique also provided unequivocal evidence for the idea that bilayer tension alone gated MS channels [101]. Although $\mathrm{ENaC}$ has also been reconstituted in lipid bilayer and reported to show stretch sensitivity, it is not clear whether the proposed mechanism of stretch-induced release of $\mathrm{Ca}^{2+}$ channel block operates in situ [75]. At this time, the best evidence for $\mathrm{ENaC}$ family members forming MS channels comes from genetic studies of $C$. elegans touch-insensitive mutants [see 8, 39, 47, 62 for reviews].

The proteins forming the other major class of MS channels in animals cells, MscK [79, 118, 150, 168], were identified serendipitously, in that after the first members of the 2 pore domain $\mathrm{K}^{+}$(K2P) channel family had already been cloned and shown to form $\mathrm{K}^{+}$channels [41, 42 , 93], they were subsequently found to be stretchactivated [6, 126, 129]. The recent demonstration that TREK and TRAAK retain stretch sensitivity in CSK-free membrane blebs indicates that they are also bilayer-gated channels [69]. In addition to the MS channel proteins that may function as mechanosensors in situ, there is also an increasing number of voltage-gated and receptorgated channels as well as peptides that form simple model channels (alamethicin and gramicidin) that display mechanosensitivity [19, 102, 115, 122, 163]. Although these channels may operate on the same general principles that confer mechanosensitivity on membrane proteins, their role, if any, as mechanotransducers remains to be demonstrated.
Mechanosensitive channel dynamics: adaptation/ desensitization/inactivation

Gating dynamics (adaptation/inactivation/desensitization) has been shown to play a critical role in the signaling by voltage- and receptor-gated channels and the hair cell mechanotransduction channel $[67,72]$ and defects in gating dynamics underlie a number of channelopathies [4]. In the initial studies of single MS channel currents, the channels seemed to obey stationary kinetics and were analyzed accordingly [46, 50, 51, 90, 114, 143, 177, 179]. However, with the ability to apply fast pressure steps to the patch [9, 59, 105-108], it became evident that MS channels also displayed dynamics in which the channels either closed reversibly (adaptation or inactivation/desensitization) or faded irreversibly (run down) with constant stimuli [55, 69, 105, 106, 156].

In principle, the reversible closure of MS channels during maintained stimulation can arise through relaxation in either the mechanical force being applied to the channel or the sensitivity to that mechanical force $[54,57]$ Because mechanical gating arises from the channel protein being sensitive to some mechanical-induced deformation [i.e., either in the bilayer or in CSK/extracellular matrix (ECM) elements], then closure can arise because of a relaxation in the force causing the deformation or a relaxation in the sensitivity to that deformation. For example, in the simplest case of a two-state channel in which the rate constants for channel opening $(\beta)$ and closing $(\alpha)$ are displacementsensitive (i.e., for a tethered MS channel) or tensionsensitive (i.e., for bilayer-gated MS channel) the probability of the channel being open $\left(P_{\mathrm{o}}\right)$ will be given by:

$P_{o}=1 /(1+K)$

where

$K=\beta / \alpha$

Or, in terms of displacement,

$K=K_{0} e^{s\left(x_{0}-x\right)}$

where $K_{0}$ is the equilibrium constant when the displacement $x$ is equal to the set point $x_{0}$ and determines the number of channels open at zero relative displacement, and $s$ is the sensitivity to the relative displacement change $\left(x_{0}-x\right)$. For a bilayer-gated channel, we can substitute displacement with area change. An exponential time relaxation in either $s$ or $x_{0}$ can produce the same adapting MS channel currents [57]. Figure 7 illustrates simulations of the stimulus-response relations made, assuming that after a step stimulus, there is an exponential change in either the set point $x_{0}$ (Fig. $7 \mathrm{a}$ ) or the sensitivity factor $s$ (Fig. 7b).

Although both mechanisms predict the same kinetics of channel closure, the consequences on the $P_{\mathrm{o}}-X$ curves are 
A

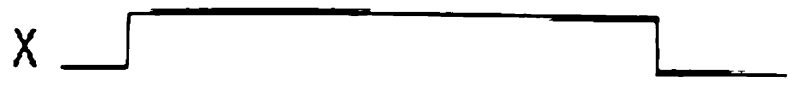

Tension

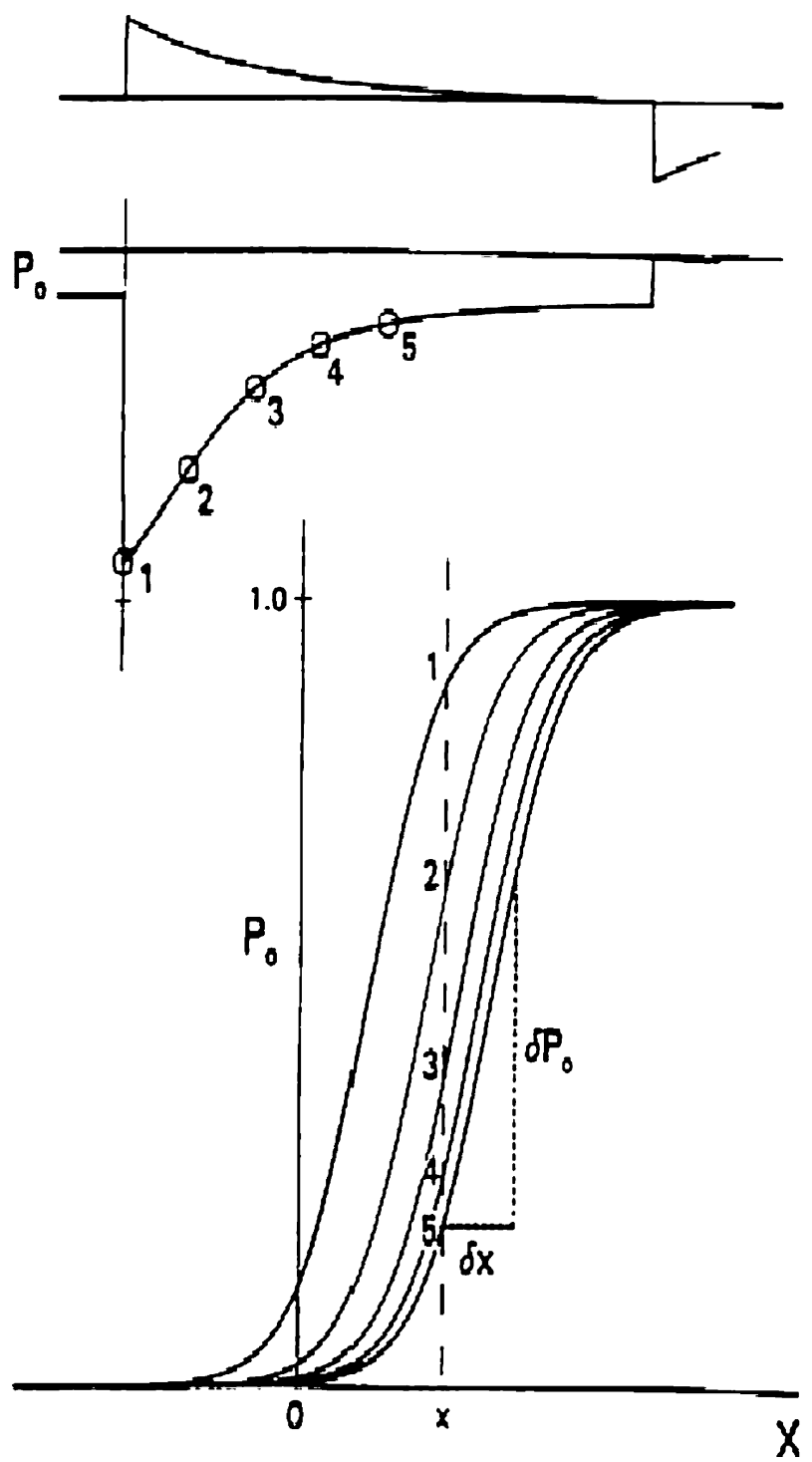

Fig. 7 Simulation of two mechanisms that results in closure of MS channels in the presence of sustained stimulation. A two-state channel is assumed, and a step displacement from 0 to $x$ (top, trace 1) is used to activate the MS channels ( $\mathbf{a}$ and $\mathbf{b}$ ). Trace 2 represents the changes in tension (a) or sensitivity tension (b). In trace 3, the channel currents are represented by the change in open-channel probability $\left(P_{\mathrm{o}}\right)$, with the numbered points (1-5) representing equally spaced times where $P_{\mathrm{o}}-X$ curves were generated to follow changes in the MS channel sensitivity. a The decay of the current is due to a change in the tension

clearly different. In the first case of adaptation, the curves shift along the $x$-axis with no changes in slope (i.e., sensitivity) around a common set point. In the second case,
B

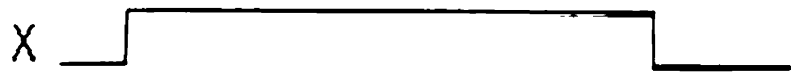

Sensitivity
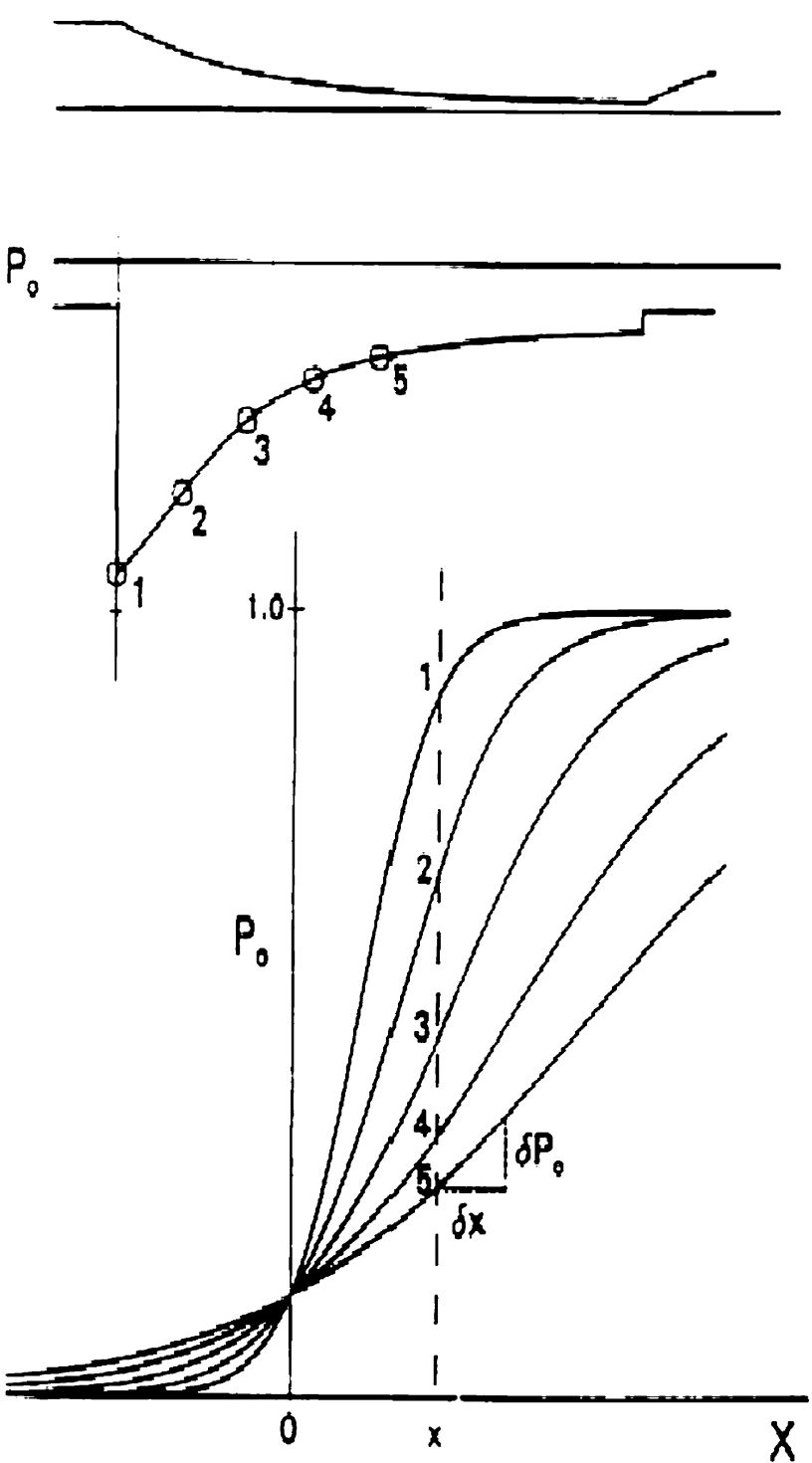

(measured as $x-x_{0}$ ) caused by a shift in the set point. In this case, there is a shift along the $x$-axis with no change in slope. Consequently, the $\delta P_{\mathrm{o}}$ response due to $\delta x$ does not decrease during what can be considered true adaptation. b The decay of the current is due to a change in sensitivity in which the slopes of the $P_{\mathrm{o}}-X$ curves decrease as they pivot around a common point. As a consequence, the incremental change in the response $\left(\delta P_{\mathrm{o}}\right)$ for a fixed $\delta x$ decreases during the current decay, which is akin to receptor desensitization. Modified from Ref. [57]

the sensitivity decreases as the curves pivot around a common point. From a functional point of view, the first case is true adaptation because sensitivity is maintained 
[55], whereas the second case is more akin to receptor desensitization or voltage-gated channel inactivation, where the stimulus must be removed for sensitivity to recover [69]. Below, we consider specific MS channels in terms of these general principles.

Msc Ca in Xenopus oocytes This channel displays different gating dynamics depending upon patch "history." In the case when the giga-seal is formed using a "gentle" suction protocol (e.g., $10 \mathrm{mmHg}$ for $1-10 \mathrm{~s}$ ), the application of a suction/pressure step produces rapid opening $(<1 \mathrm{~ms})$ of channels followed by a slower closure $(\sim 100 \mathrm{~ms})$, although the stimulus is maintained constant. The resultant decay of $\mathrm{MscC}$ a current can be fitted by a single exponential with a time constant of around $100 \mathrm{~ms}$ at $-100 \mathrm{mV}$ that shows a monotonic $e$-fold increase for every approximately $100-\mathrm{mV}$ depolarization. The voltage dependence of the channel closure is most evident when the voltage is switched from hyperpolarized to depolarized potential (or vice versa) during the pressure step (Fig. 8) [55, 107, 108]. The direction of this voltage dependence is similar to the voltage dependence of adaptation displayed by the hair cell mechanotransducer channel [5] and MscS (see below). The stimulus induced closure of the oocyte channel was originally referred to as adaptation because increasing the stimulus could reopen channels. In the oocyte, suctions/ pressures of approximately $20 \mathrm{mmHg}$ produce saturating responses (see Fig. 4), so it was assumed that any channel opening caused by an increase in suction/pressure of at least $20 \mathrm{mmHg}$ would involve reopening channels that had just closed. However, a practical limitation in using these protocols on oocyte patches is that application of even larger pulses (e.g., $\geq 40 \mathrm{mmHg}$ ) that would undoubtedly activate all channels will also cause irreversible loss of the channel activity and gating dynamics as described below $[55,105,106]$.

In the second case, if a more forceful suction protocol is required to achieve the seal, then more often than not, the transient current response is absent, and instead, the channels remain open for the full duration of the suction. Similarly, if after a gentle seal is formed the patch is mechanically "over-stimulated," then adaptation of $\mathrm{MscCa}$ activity disappears either progressively with each moderatesized pulse (Fig. 9a) or suddenly within a single large suction (Fig. 9b). This transition from the transient mode (TM) to the sustained mode (SM) of gating is irreversible and occurs without a change in single-channel conductance [64].

The fragility of MscCa dynamics and the transition from TM to SM gating has been proposed to arise through mechanical decoupling of CSK interactions with either the channel or the membrane, which are thought to be important for TM of gating. It has been suggested that viscous elements (dashpots) in the CSK can become frozen or decoupled without disconnecting the gating springs. However, adaptation is preserved in both inside-out and outside-out patches, and in patches treated with agents that disrupt microtubules (colchicine) or microfilaments (cytochalasin D), similar to what has been reported for TRAAK desensitization [69]. In contrast, transient gating kinetics of $\mathrm{MscCa}$ are not retained in either "blebbed" membrane that it lacks an underlying CSK [185] or in pure liposome patches expressing MscCa activity following reconstitution of detergent-solubilized oocyte membrane proteins [97]. Furthermore, overexpression of TRPC-1 that forms the oocyte $\mathrm{MscCa}$ does not result in channel activity that displays TM gating. Whether the absence of adaptation reflects prior mechanodisruption or the absence of CSK remains unclear, as does the mechanism that causes irreversible run down. One possibility is that there are

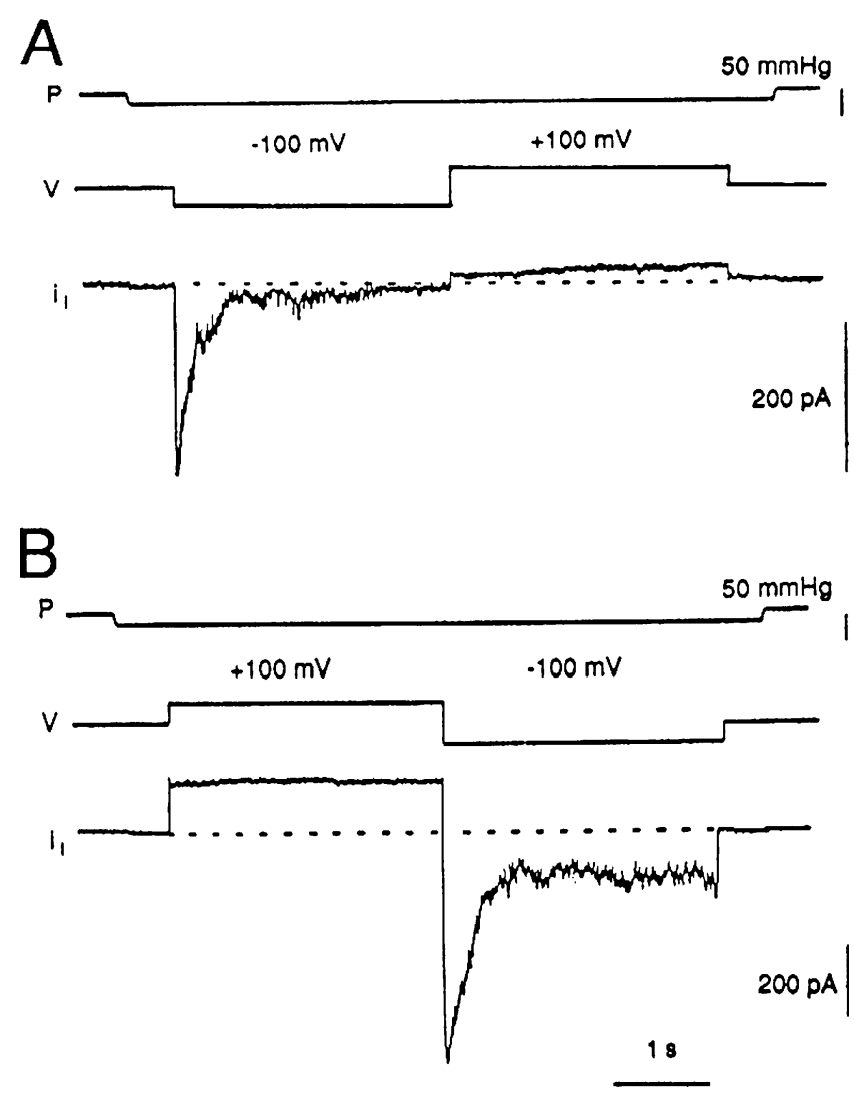

Fig. 8 Voltage dependence of pressure-induced currents recorded from cell-attached oocyte patches. In each panel, the top trace represents the pressure (suction); the middle trace, the voltage; and the bottom trace, the current. a The application of the suction pulse to the patch held at $-100 \mathrm{mV}$ caused rapid opening of channels that had nearly all closed before the voltage was switched to $100 \mathrm{mV}$ while maintaining the suction pulse. $\mathbf{b}$ In this case, the suction was applied to the patch held $100 \mathrm{mV}$ and produced a steady-state current. Switching the voltage to $-100 \mathrm{mV}$ activated a transient increase in current that decayed incompletely in the presence of maintained suction 
Fig. 9 Irreversible loss of transient mode gating of MscCa. a Three consecutive suction pulses of $30 \mathrm{mmHg}$ were applied to a patch $30 \mathrm{~s}$ apart, causing a progressive loss of the transient gating and a decrease in the peak current. b A single large suction pulse $(100 \mathrm{mmHg}$, $10 \mathrm{~s})$ was applied to a patch and caused an initial peak current that was converted into a sustained current
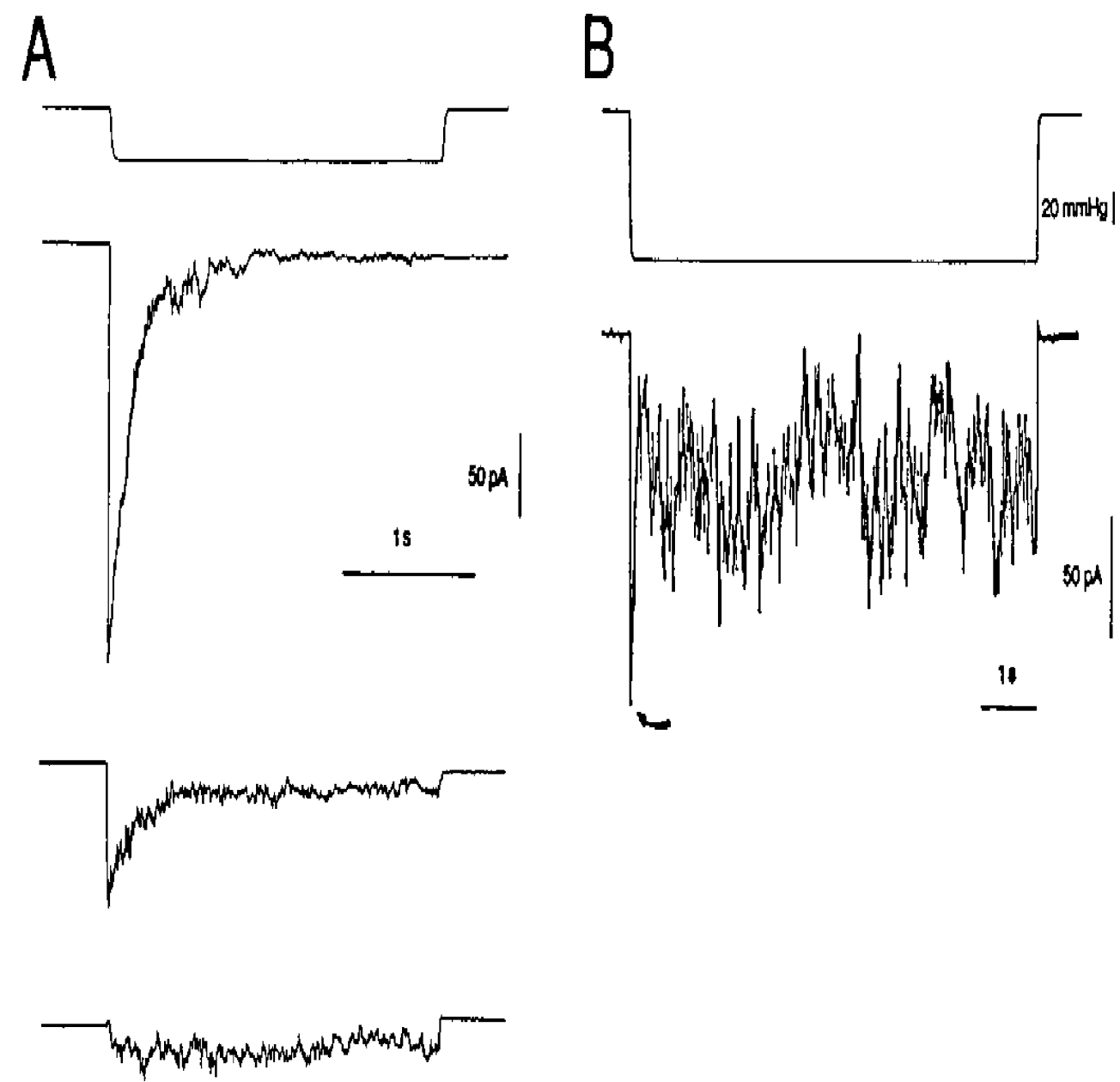

irreversible changes in the membrane-glass adhesion that alters the ability to generate tension changes in the bilayer. For example, if the membrane does not reseal after mechanical decoupling of lipid-glass interface [121], then increasing pressure may draw further membrane into the pipette without increasing bilayer tension.

Msc Ca in rat astocytes This channel shows certain dynamic properties similar to those of the oocyte $\mathrm{MscCa}$, including its voltage dependence and mechanical fragility. However, in the astrocyte, the decrease in current occurs because of increased occupancy of lower conductance states and a reduced open-channel probability [13, 156]. Furthermore, the closed channels cannot be reactivated by increasing the stimulus strength (i.e., are refractory), indicating inactivation rather than adaptation. The process was modeled as a ball-and-chain-type inactivation, in which the inactivating ball was a CSK element rather than part of the channel protein. By assuming that the binding rates of the inactivating ball were affected by the position of an intramembrane voltage-sensing subunit, one can account for the voltage dependence of inactivation. Apparently consistent with the model, it was demonstrated that a combination of agents targeting actin (cytochalasin), microtubules (colchicine), and intermediate filaments (acrylamide) was required to abolish the inactivation, but this loss might again reflect general mechanical patch damage rather than implicating specific CSK elements. In the same study, fast $C_{\mathrm{m}}$ measurements were used to monitor the change in membrane area/thickness during pressure steps and demonstrated a similar voltage-independent monotonic increase in patch capacitance at -90 and $+50 \mathrm{mV}$, which contrasted with the voltage-dependent inactivation. This observation was interpreted as indicating inactivation was due to intrinsic properties of the channel rather than relaxation of bilayer tension [156].

MscS and MscL in Escherichia coli The two predominant MS channels in Escherichia coli, MscS (0.5 pS) and MscL (1-3 nS) [100, 160], also exhibit transient gating dynamics [2, 66, 86, 87]. MscS currents measured in E. coli protoplasts in response to pressure steps undergo a pressure-induced exponential decay that appeared to be voltage-independent with a time constant of 2-3 s when measured over a narrow voltage range of $\pm 30 \mathrm{mV}$ [86]. However, when measured over a wider voltage range of 
$\pm 100 \mathrm{mV}$ there was a decrease in the rate of inactivation with depolarization similar to $\mathrm{MscCa}$ [2]. Application of the second of a double-step protocol activates fewer channels, and a finite time without stimulation is required for recovery of the full response [86]. Furthermore, suction ramps produced smaller peak responses than suction steps [2]. These features are more consistent with inactivation than adaptation. Unlike $\mathrm{MscCa}$ in vertebrate cells, $\mathrm{MscS}$ dynamics are not mechanically fragile, although pronase treatment of the intracellular membrane face abolishes the transient kinetics and, ultimately, mechanosensitivity. This last observation led Koprowski and Kubalski to propose that both activation and inactivation may depend upon interaction between a cytoplasmic (pronase-sensitive) region of the channel with the lipid bilayer [86, 87]. Note the proteolytic inhibition of $\mathrm{MscS}$ activity is opposite to the potentiation of MscL activity [1]. Given that a bilayer rather than a tethered mechanism gates $\mathrm{MscS}$, it was proposed that inactivation might be associated with insertion of the cytoplasmic domain of $\mathrm{MscS}$ in the bilayer (i.e., a "hybrid" or intrinsic tethered model; see below).
MscL reconstituted in liposomes also shows a transient decay in the current with a time constant of seconds [66]. Although the distinction between adaptation and inactivation still needs to be made, the observation is significant because the clear absence of any CSK excludes its involvement in these transient kinetics. One possible explanation is timedependent sliding/relaxation of the two monolayers that results in relaxation of the gating tension [144].

TREK and TRAAK MS channels In a recent study, pressure steps have been used to analyze the dynamics of MscK formed by cloned TREK-1 and TRAAK herologously expressed in COS cells and Xenopus oocytes [69]. Both channels show rapid closure ( $\tau \sim 20-50 \mathrm{~ms})$, with constant stimulation similar to the MscCa. However, unlike MscCa, MscK gating dynamics are not voltage-sensitive, and either mechanical or chemical disruption (i.., using latrunculin) of the CSK causes "run up" rather that "run down" of the channels without removing the transient gating kinetics. Because it was clearly demonstrated that channels could not be reactivated without a finite time for recovery, the phenomenon was referred to as desensitization. The lack
Fig. 10 Three different models of mechanosensitive channel gating a Bilayer. Mechanical forces are conveyed to the channel purely via the bilayer. Tension sensitivity occurs because of a difference protein area (or hydrophobic thickness and/or lateral shape) between the open and closed channel conformations. b Extrinsic tether. Tensions are exerted directly on the channel protein via extracellular or cytoskeletal elastic elements/gating springs. When tension is exerted on the gating spring, the open state is energetically more favorable. Intrinsic tether (hybrid). In this model, the gating spring is one of the cytoplasmic domains that binds to the phospholipids and, in this way, becomes sensitive to membrane stretch
A
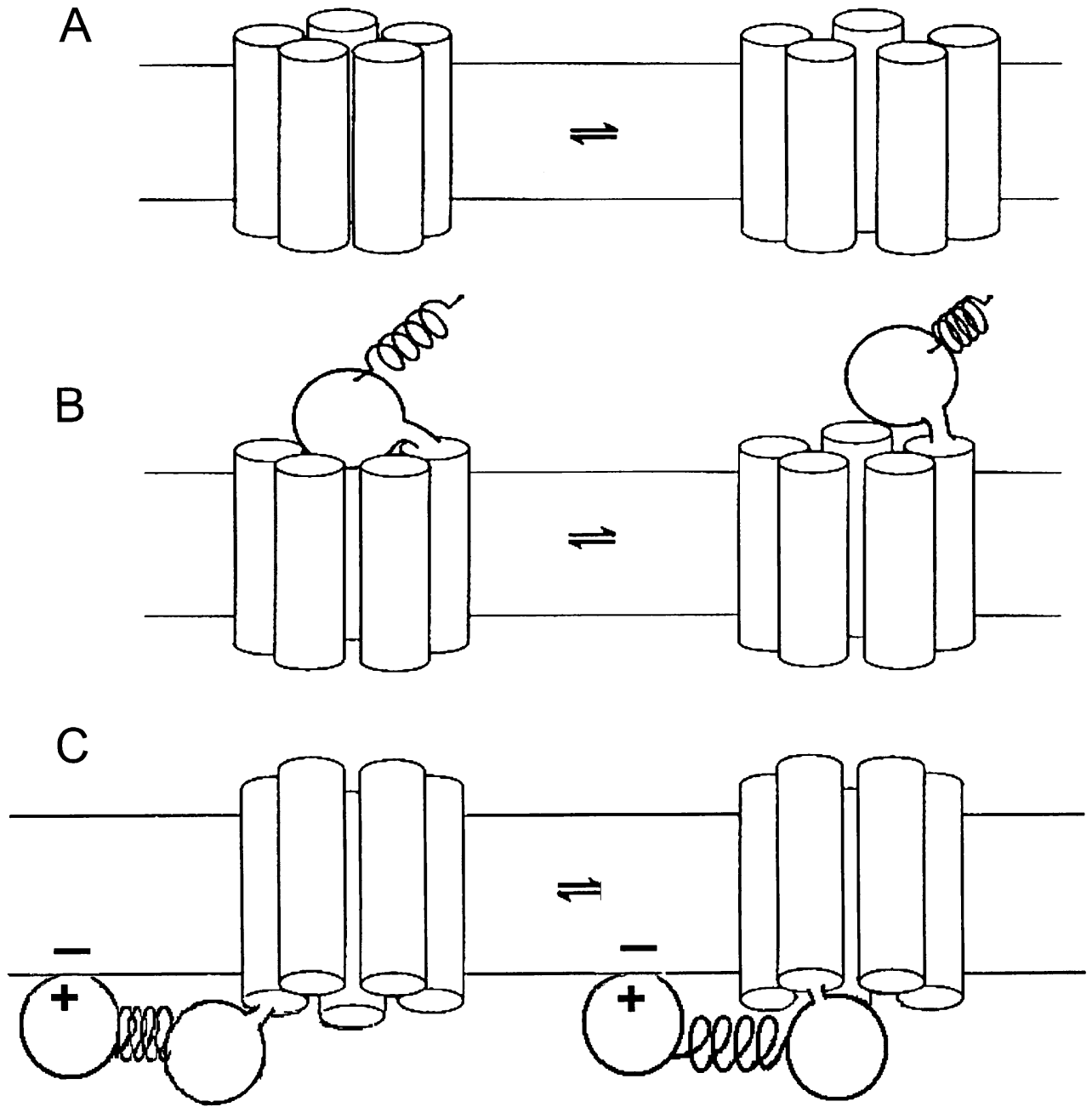
of effects of either mechanical or chemical CSK disruption indicates that desensitization is an intrinsic property of the channel [69].

Molecular models of stretch sensitivity

There are three broad classes of mechanisms that may impart stretch sensitivity on a membrane ion channel. They will be referred to as "bilayer," "tethered," and "hybrid," and are shown schematically in Fig. 10. The models need not be mutually exclusive, and a single channel may derive its mechanosensitivity from all three mechanisms. Each mechanism can be discussed in terms of a simple two-state channel that fluctuates between a closed and open state. The bilayer mechanism applies to a variety of MS channels, as evidenced by retention of mechanosensitivity following liposome reconstitution and/or activation by amphipaths or lysophospholipids. The basic idea is that stretching the bilayer will tend to decrease its lipid packing density and thickness, so that if the channel protein undergoes a change in membraneoccupied area (Fig. 9a) and/or hydrophobic mismatch, there will be a shift in the distribution between closed and open channel conformations [54, 88, 95]. By inserting in the membrane, lysophospholipids and amphipathic molecules may cause local changes in tension and curvature at the lipid-protein interface and thereby shift the channel distribution [12, 95, 98, 99, 131-133].

In the tethered mechanism, either an extracellular or cytoskeletal protein is directly connected to the channel and acts as a gating spring $[50,58,62,71,72]$. When the gating spring is stretched, it favors the open state of the channel because it allows relaxation of the spring. In
Fig. 9b, the gate is represented as a trapdoor that opens out, but it can well represent subunits that are either pulled apart (increased in area) or lengthened (change if hydrophobic mismatch). Evidence pro and con for the tethered mechanism has been discussed previously [54, 88].

The hybrid of the above two mechanisms depends upon stretching of the bilayer, but in this case, there are cytoplasmic domains of the channel protein that bind to phospholipids, and in this way act as intrinsic tethers or gating springs that are stretched along with the bilayer (Fig. 9c). Evidence for the hybrid model comes from the identification in the specific K2P channels of a phospholipid-sensing domain on the proximal carboxyl terminus that involves a cluster of positively charged residues that also includes the proton sensor E306 [23, 68]. Protonation of E306 drastically tightens channel-phospholipid interaction and leads to TEK-1 opening at atmospheric pressure. The carboxy terminal domain of TREK-1 interacts with plasma membrane, probably via electrostatic interaction between a cluster of positive charges (a PIP2-interacting domain) and anionic phospholipids.

Mechanosensitive channels in human diseases

An exiting development in the field has been the growing number of diseases associated with abnormalities of mechanotransduction. Donald Ingber [73], in a recent review, listed 45 diseases that may arise due to changes in cell mechanics, alterations in tissue structure, or deregulation of mechanosignaling pathways. Of these diseases, several have been directly associated with changes in expression and/or gating of MS channels, including cardiac arrhythmias [84], polycystic kidney disease [18], hyperten-
Fig. 11 Cell-attached patch recording on an $m d x$ mouse myotube showing high constitutive channel activity that was reduced with suction but unaffected by positive pressure. This "apparent" stretch-inactivated channel activity was rare and seen in only 1 of approximately 100 patches. The majority of other patches showed no spontaneous channel activity, and suction activated either a transient opening of channels or channels that remained open for $10 \mathrm{~s}$ after the pulse (e.g., see [107])

\section{$m d x$ mouse skeletal muscle}
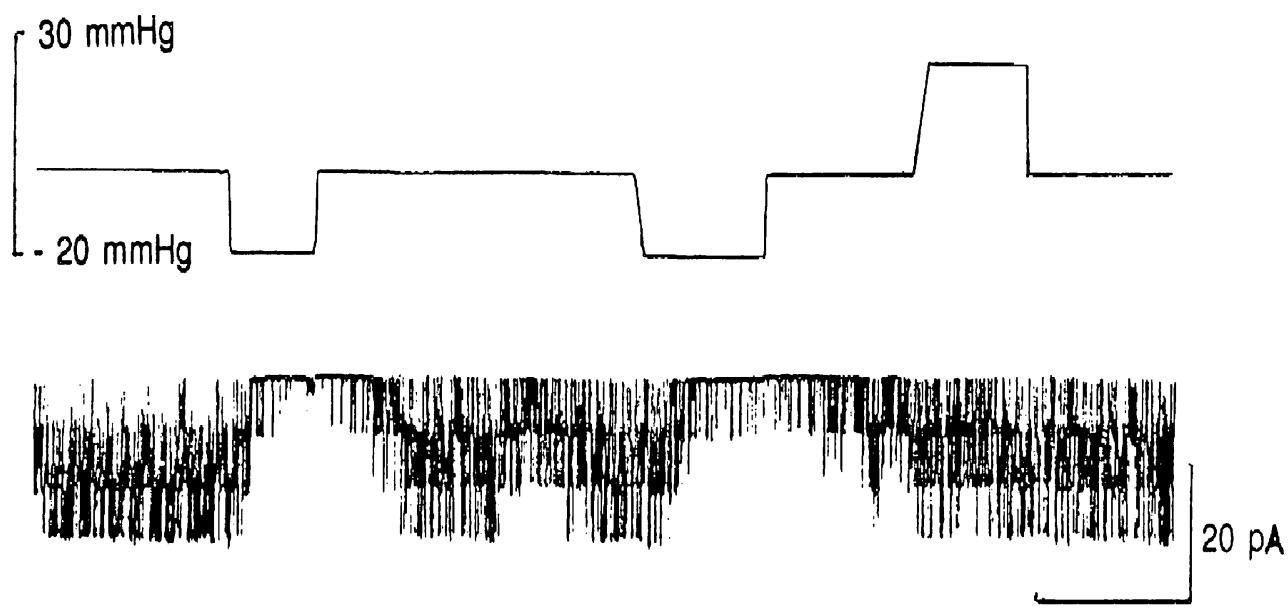

$5 \mathrm{~s}$ 
sion [83], glioma [123], glaucoma [78] atherosclerosis [22, 134], Duchenne muscular dystrophy [44, 45], and tumorigenesis [128]. Furthermore, increased MscK activity has been shown to prevent brain ischemia [16] and promote general anesthesia [127], whereas MscCa/TRPC activity may regulate wound healing [137] and promote neuronal regeneration [76]. Of particular note is Duchenne muscular dystrophy (DMD), a devastating X-linked genetic disease that affects approximately 1 in 3,500 male births and is characterized by progressive muscle wasting and weakness (reviewed in [180]). DMD is caused by the absence of the gene product of dystrophin, a cytoskeletal protein that binds to actin and provides structural support for the membrane particularly during muscle stretching. In $m d x$ muscle fibers (i.e., from the mouse model of DMD), there is increased vulnerability to stretch-induced membrane wounding, and several studies indicate elevated $\left[\mathrm{Ca}^{2+}\right]_{\mathrm{i}}$ levels in $m d x$ myotubes that have been associated with increased $\mathrm{Ca}^{2+}$ permeant leak channel activity [43] and/or abnormal $\mathrm{MscCa}$ activity [44, 45]. Anti-MscCa agents, including $\mathrm{Gd}^{3+}$, streptomycin, amiloride, and GsMTx-4, have been reported to block $\mathrm{Ca}^{2+}$ elevation and/or reduce muscle fiber degeneration $[3,56]$. Based on the observation that the leak channel activity was increased by internal calcium store depletion, Vandebrouck et al. [167] proposed that a store-operated $\mathrm{Ca}^{2+}$ channel (SOCC) belonging to the TRPC family may be involved. To test this idea, they transfected muscles with antisense oligonucleotide designed against the most conserved region sequences of the TRPCs and showed it caused significant knockdown of TRPC-1 and - 4 but not TRPC-6 (all three were detected in wildtype and $m d x$ muscle), and reduced both control and thapsigagin-induced $\mathrm{Ca}^{2+}$ leak channels without affecting voltage-gated $\mathrm{Na}^{+}$channels. The mechanosensitivity of the channels was not tested in this study. However, MscCa can show significant spontaneous opening in the absence of membrane stretch [140]. Furthermore, although Franco and Lansman [44] initially reported a stretch-inactivated $\mathrm{Ca}^{2+}$ channel in $m d x$ mice, they subsequently concluded that the channel activity may arise from a novel gating mode of $\mathrm{MscCa}$ induced by membrane stress [45]. Most recently, it has been suggested that stretch inactivation in patches of $m d x$ muscle and other cells may be a patch recording artifact induced when suction applied to the patch reduces a tonic tension generated by CSK forces that bend the patch toward the cell [69]. At least consistent with this notion is that suction (but not positive pressure) causes inactivation of $\mathrm{MscCa}$ in $m d x$ patches (Fig. 11).

\section{Conclusion and future prospects}

The giga-seal patch clamp technique has been a major contributor to increased understanding of MS channels over the last 20 odd years. However, there is still somewhat a disconnect between the phenomena seen in the patch and how they translate in MS currents in the whole cell. Furthermore, given the growing evidence that MS channels are promiscuous in terms of their modes of activation, it becomes even more important to identify the exact physiological stimulus that activates the channel in specific situations. The development of new techniques that can monitor/generate membrane tension changes in normally operating cells while recording MS channel on the cell can address many of the unresolved issues. Similarly, the discovery of high affinity and selective agents that can target mechanically gated channels will represent a major breakthrough for the field. The determination of the crystal structure of bacterial MS channels [7, 21, 139] has provided a rich environment for model building and testing, and a similar trajectory is predicted for the recently identified MS channel proteins in animal cells. A key question that these studies should answer is whether a unified set of principles can account for the stretch sensitivity of channels in both prokaryotes and eukaryotes $[54,88]$.

Acknowledgments Research in the author's laboratory is funded by the National Institutes of Health (NIH) and the Department of Defense (DOD).

\section{References}

1. Ajouz B, Berrier C, Besnard M, Martinac B, Ghaz A (2000) Contributions of the different extramembranous domains of the mechanosensitive ion channel MscL to its response to membrane tension. J Biol Chem 275:1015-1022

2. Akitake B, Anishkin A, Sukharev S (2005) The "dash-pot" mechanism of stretch-dependent gating in MscS. J Gen Physiol 125:143-154

3. Allen DG, Whitehead NP, Yeung EW (2005) Mechanisms of stretch-induced muscle damage in normal and dystrophic muscle: role of ionic changes. J Physiol 567.3:723-735

4. Ashcroft FM (2006) From molecule to malady. Nature 440:440 447

5. Assad JA, Hacohen N, Corey DP (1991) Voltage dependence of adaptation and active bundle movement in bull frog saccular hair cells. Proc Natl Acad Sci USA 86:2918-2922

6. Bang H, Kim Y, Kim D (2000) TREK-2, a new member of the mechanosensitive tandem-pore $\mathrm{K}^{+}$channel family. J Biol Chem 275:17412-17419

7. Bass RB, Strop P, Barclay M, Rees DC (2002) Crystal structure of Escherichia coli $\mathrm{MscS}$, a voltage-modulated and mechanosensitive channel. Science 298:1582-1592

8. Bazopoulou D, Tavernarakis N (2007) Mechanosensitive ion channels in Caenorhabditis elegans. In: Hamill OP (ed) Mechanosensitive channels. Elsevier, Amsterdam (in press)

9. Besch SR, Suchyna T, Sachs F (2002) High speed pressure clamp. Pflugers Achiv 445:161-166 
10. Bielfeld-Ackermann A, Range C, Korbmacher C (1998) Maitotoxin (MTX) activates a nonselective cation channel in Xenopus laevis oocytes. Pflugers Archiv 436:329-337

11. Bittner GD, Fishman HM (2000) Axonal sealing following injury. In: Ingola N, Murray M (eds) Nerve regeneration. Dekker, New York, pp 337-370

12. Blount P (2003) Molecular mechanisms of mechanosensation: big lessons from small cells. Neuron 37:731-734

13. Bowman CB, Lohr JW (1996) Mechanotransducing ion channels in C6 glioma cells. Glia 18:161-176

14. Brereton HM, Chen J, Rychkov G, Harland ML, Barritt GJ (2001) Maitotoxin activates an endogenous non-selective cation channel and is an effective initiator of the activation of the heterologously expressed hTRPC1 (transient receptor potential) non-selective cation channel in H4-IIE liver cells. Biochim Biophys Acta 1540:107-126

15. Bryan-Sisneros AA, Fraser SP, Djamgoz MBA (2003) Electrophysiological mechanosensitive responses of Xenopus laevis oocytes to direct, isotonic increase in intracellular volume. J Neurosci 125:103-111

16. Buckler KJ, Honore E (2005) The lipid-activated two pore domain $\mathrm{K}^{+}$channel TREK-1 is resistant to hypoxia: implication for ischaemic neuroprotection. J Physiol 562.1:213-222

17. Caldwell RA, Clemo HF, Baumgarten CM (1998) Using gadolinium to identify stretch-activated channels: technical considerations. Am J Physiol C619-C621

18. Cantiello HF (2003) A tale of two tails: ciliary mechanotransduction in ADPKD. Trends Mol Med 9:234-236

19. Casado M, Ascher P (1998) Opposite modulation of NMDA receptors by lysophospholipids and arachidonic acid: common features with mechanosensitivity. J Physiol 513:317-330

20. Cemerikic D, Sackin H (1993) Substrate activation of mechanosensitive, whole cell currents in renal proximal tubule. Am J Physiol 264:F697-F714

21. Chang G, Spencer RH, Lee AT, Barclay MT, Rees DC (1998) Structure of the mscL homolog from Mycobacterium tuberculosis: a gated mechanosensitive ion channel. Science 282:220 2226

22. Chapleau MW, Cunningham JT Sullivan MJ, Wachtel RE Abboud FM (1995) Structural versus functional modulation of the arterial baroreflex. Hypertension 26:341-347

23. Chemin J, Patel AJ, Duprat F, Lauritzen I, Lazdunski M, Honore E (2005) A phospholipid sensor controls mechanogating of the $\mathrm{K}^{+}$channel TREK-1. EMBO J 24:44-53

24. Chen BM, Grinnell AD (1995) Integrins and modulation of transmitter release from motor terminals by stretch. Science 269:1578-1580

25. Chen P, Hwang TC, Gillis KD (2001) The relationship between cAMP, $\mathrm{Ca}^{2+}$ and transport of CFTR to the plasma membrane. J Gen Physiol 118:135-144

26. Christensen O (1987) Mediation of cell volume regulation by $\mathrm{Ca}^{2+}$ influx through stretch-activated cation channels. Nature 330:66-68

27. Clapham DE (2003) TRP channels as cellular sensors. Nature 426:517-524

28. Dai J, Sheetz MP (1999) Membrane tether formation from blebbing cells. Biophys J 77:3363-3370

29. Dai J, Sheetz MP (1995) Mechanical properties of neuronal growth cone membranes studied by tether formation with laser tweezers. Biophys J 68:988-996

30. Dai J, Sheetz MP, Wan X, Morris CE (1998) Membrane tension in swelling and shrinking molluscan neurons. J Neurosci 18:6681-6692

31. Dai J, Ting-Beall HP, Sheetz MP (1997) The secretion-coupled exocytosis correlates with membrane tension changes in RBL 2H3 cells. J Gen Physiol 110:1-10
32. Disher DE, Mohandas N (1996) Kinematics of red cell aspiration by fluorescence-imaged microdeformation. Biophys J 71:1680-1694

33. Discher DE, Mohandas N, Evans EA (1994) Molecular maps of red cell deformation: hidden elasticity and "it situ" connectivity. Science 266:1032-1035

34. Drummond HA, Gebremedhim D, Harder DR (2004) Degenerin/ Epithelial $\mathrm{Na}^{+}$channel protein. Components of a vascular mechanosensor. Hypertension 44:643-648

35. Dunina-Barkovskaya AY, Levina NN, Lew RR, Heath IB (2004) Gadolinium effects on gigaseal formation and the adhesive properties of a fungal amoeboid cell, the slime mutant of Neurospora crassa. J Membr Biol 198:77-87

36. Dutta R, Robinson KR (2004) identification and characterization of stretch-activated ion channels in pollen protoplasts. Plant Physiol 135:1398-1406

37. Erickson CA, Trinkaus JP (1976) Microvilli and blebs as sources of reserve surface membrane during cell spreading. Exp Cell Res 99:375-384

38. Ermakov YA, Averbakh AZ, Yusipovich AI, Sukarev S (2001) Diploe potentials indicate restructuring of the membrane interface induced by gadolinium and beryllium ions. Biophys $\mathrm{J}$ 80:1851-1862

39. Ernstrom GG, Chalfie M (2002) Genetics of sensory mechanotransduction. Ann Rev Genet 36:411-453

40. Escobar LI, Salvador C, Martinez M, Vaca L (1998) Maitotoxin, a cationic channel activator. Neurobiology 6:59-74

41. Fink M, Duprat F, Lesage F, Reyes R, Romey G, Heurteaux C, Lazdunski M (1996) Cloning, functional expression and brain localization of a novel unconventional outward rectifier $\mathrm{K}^{+}$ channel. EMBO J 15:6854-6862

42. Fink M, Lesage F, Duprat F, Heurteaux C, Reyes R, Fosset M, Lazdunski M (1998) A neuronal two pore $\mathrm{K}^{+}$channel activated by arachidonic acid polyunsaturated fatty acids. EMBO J 17:3297-3308

43. Fong P, Turner PR, Denetclaw WF, Steinhardt RA (1990) Increased activity of calcium leak channels in myotubes of Duchenne human and mdx mouse origin. Science 250:673-676

44. Franco A, Lansman JB (1990) Calcium entry through stretchinactivated channels in $m d x$ myotubes. Nature 344:670-673

45. Franco-Obregon A, Lansman JB (2002) Changes in mechanosensitive channel gating following mechanical stimulation in skeletal muscle myotubes from the mdx mouse. J Physiol 539.2:391-407

46. Gil Z, Magleby KL, Siberberg SD (2001) Two-dimensional kinetic analysis suggests nonsequential gating of mechanosensitive channels in Xenopus oocytes. Biophys J 81:2082-2089

47. Goodman MB, Schwarz EM (2003) Transducing touch in Caenorhabditis elegans. Ann Rev Physiol 65:429-452

48. Gottlieb PA, Suchyna TM, Ostrow LW, Sachs F (2004) Mechanosensitive ion channels as drug targets. Curr Drug Targets 3:287-295

49. Gottlieb PA, Suchyna TM, Sachs F (2007) Properties and mechanism of the mechanosensitive ion channel blocker GsMTx4, a therapeutic peptide derived from tarantula venom. In: Hamill OP (ed) Mechanosensitive channels. Elsevier, Amsterdam (in press)

50. Guharay F, Sachs F (1984) Stretch-activated single ion channel currents in tissue cultured embryonic chick skeletal muscle. J Physiol 352:685-701

51. Guharay F, Sachs F (1985) Mechanotransducer ion channels in chick skeletal muscle: the effects of extracellular $\mathrm{pH}$. J Physiol 363:119-134

52. Hamill OP (1983) Potassium and chloride channels in red blood cells. In: Sakmann B, Neher E (eds) Single channel recording. Plenum, New York, pp 451-471 
53. Hamill OP, Marty A, Neher E, Sakmann B, Sigworth F (1981) Improved patch clamp techniques for high current resolution from cells and cell-free membrane patches. Pflugers Arch 391:85-100

54. Hamill OP, Martinac B (2001) Molecular basis of mechanotransduction in living cells. Physiol Revs 81:685-740

55. Hamill OP, McBride DW Jr (1992) Rapid adaptation of the mechanosensitive channel in Xenopus oocytes. Proc Natl Acad Sci USA 89:7462-7466

56. Hamill OP, Lane JW, McBride DW Jr (1992) Amiloride: a molecular probe for mechanosensitive channels. Trends Pharmacol Sci $13: 373-376$

57. Hamill OP, McBride DW Jr (1994) Molecular mechanisms of mechanoreceptor adaptation. News Physiol Sci 9:53-59

58. Hamill OP, McBride DW Jr (1994) The cloning of a mechanogated membrane channel. Trends Neurosci 17:11:439-443

59. Hamill OP, McBride DW Jr (1995) Pressure/patch-clamp methods. In: Boulton AA, Baker GB, Walz W (eds) Patch clamp techniques and protocols. Humana, Totowa, pp 75-87

60. Hamill OP, McBride DW Jr (1995) Mechanoreceptive membrane ion channels. Am Sci 83:30-37

61. Hamill OP, McBride DW Jr (1996) The pharmacology of mechanogated membrane ion channels. Pharmacol Rev 48:231-252

62. Hamill OP, McBride DW Jr (1996) A supramolecular complex underlying touch sensitivity. Trends Neurosci 19:258-261

63. Hamill OP, McBride DW Jr (1997) Induced membrane hypo-/ hyper-mechanosensitivity: a limitation of patch clamp recording. Annu Rev Physiol 59:621-631

64. Hamill OP, McBride DW Jr (1997) Mechanogated channels in Xenopus oocytes: different gating modes enable a channel to switch from a phasic to a tonic mechanotransducer. Biol Bull 192:121-122

65. Hamill OP, McBride DW Jr (1998) Drug effects on mechano-gated channels. In: Soria B, Cena V (eds) The pharmacology of membrane ion channel. Oxford University Press, Oxford, pp 271-278

66. Häse CC, Le Dain AC, Martinac B (1995) Purification and functional reconstitution of the recombinant large mechanosensitive ion channel (MscL) of Escherichia coli. J Biol Chem 270:18329-18334

67. Hille B (2001) Ion channels of excitable membranes, 3rd edn. Sinauer, Sunderland, pp 1-814

68. Honoré E, Maingret F, Lazdunski M, Patel AJ (2002) An intracellular proton sensor commands lipid and mechano-gating of the $\mathrm{K}^{+}$channel TREK-1. EMBO J 21:2968-2976

69. Honoré E, Patel AJ, Chemin J, Suchyna T, Sachs F (2006) Desensitization of mechano-gated K2P channels. Proc Natl Acad Sci USA 103:6859-6864

70. Hörber JKH, Mosbacher J, Häbele W, Ruppersberg JP, Sakmann B (1995) A look at membrane patches with scanning force microscope. Biophys J 68:1687-1693

71. Howard J, Bechstedt S (2004) Hypothesis: a helix of ankyrin repeats of the NOMPC-TRP ion channel is the gating spring of mechanoreceptors. Curr Biol 14:224-226

72. Howard J, Roberts WM, Hudspeth AJ (1988) Mechanoelectrical transduction by hair cells. Annu Rev Biophys Chem 17:99-124

73. Ingber DE (2003) Mechanobiology and diseases of mechanotransduction. Ann Med 35:1-14

74. Inoue R, Okada T, Onoue H, Hara Y, Shimizu S, Naitoh S, Ito Y, Mori Y (2001) The transient receptor potential protein homologue TRP6 is the essential component of vascular 1adrenoceptor-activated $\mathrm{Ca}^{2+}$-pereable cation channel. Circ Res $88: 325-332$

75. Ismailov II, Berdiev BK, Shlyonsky VG, Benos DJ (1997) Mechanosensitivity of an epithelial $\mathrm{Na}^{+}$channel in planar lipid bilayers: release from $\mathrm{Ca}^{2+}$ block. Biophys J 72:1182-1192
76. Jacques-Fricke BT, Seow Y, Gottlieb PC, Sachs F, Gomez TM (2006) $\mathrm{Ca}^{2+}$ influx through mechanosensitive channels inhibits neurite outgrowth in opposition to other influx pathways and release of intracellular stores. J Neurosci 26:5656-5664

77. Jung S, Mühle A, Shaefer M, Strotmann R, Schultz G, Plant TD (2003) Lanthanides potentiate TRPC5 currents by an action at the extracellular sites close to the pore mouth. J Bio Chem 278:3562-3571

78. Kalapesi FB, Tan JCH, Coroneo MT (2005) Stretch-activated channels; a mini-review: are stretch-activated channels an ocular barometer? Clin Exp Opthal 33:210-217

79. Kim D (1992) A mechanosensitive $\mathrm{K}^{+}$channel in heart cells activation by arachidonic acid. J Gen Physiol 100:1021-1040

80. Kleyman TR, Cragoe EK (1988) Amiloride and its analogs in the study of ion transport. J Membr Biol 105:1-21

81. Kloda A, Martinac B (2001) Mechanosensitive channels of Thermoplasma, the cell wall-less Archaea. Cell Biochem Biophys 34:321-347

82. Knutton S, Jackson D, Grahman JM, Micklem KJ, Pasternak CA (1976) Microvilli and cell swelling. Nature 262:52-53

83. Kohler R, Distler A, Hoyer J (1999) Increased mechanosensitive currents in aortic endothelial cells from genetically hypertensive rats. J Hypertens 17:365-371

84. Kohl P, Franz, MR, Sachs F (2002) Cardiac mechano-electric feedback and arrhythmias: from pipette to patient. Elsevier, Amsterdam

85. Konoki K, Hashimoto M, Muata M, Tachibana K (1999) Maitotoxin-induced calcium influx in erythrocyte ghosts and rat glioma C6 cells and blockade by gangliosides and other membrane lipids. Chem Res Toxicol 12:993-1001

86. Koprowski P, Kubalski A (1998) Voltage-independent adaptation of mechanosensitive channel in Escherichia coli protoplasts. J Membr Biol 164:253-262

87. Koprowski P, Kubalski A (2003) C termini of the Escherichia coli mechanosensitive ion channel (MscS) move apart upon the channel opening. J Biol Chem 278:11237-11245

88. Kung C (2005) A possible unifying principle for mechanosensation. Nature 436:647-654

89. Lane JW, McBride DW Jr, Hamill OP (1993) Ionic interactions with amiloride block of the mechanosensitive channel in Xenopus oocytes. Br J Pharmacol 108:116-119

90. Lane JW, McBride DW Jr, Hamill OP (1992) Structure-activity relations of amiloride and some of its analogues in blocking the mechanosensitive channel in Xenopus oocytes. Br J Pharmacol 106(2):283-286

91. Lane J, McBride DW Jr, Hamill OP (1991) Amiloride block of the mechanosensitive cation channel in Xenopus oocytes. J Physiol 441:347-366

92. Lee J, Ishihara A, Oxford G, Johnson B, Jacobson K (1999) Regulation of cell movement is mediated by stretch-activated calcium channels. Nature 400:382-386

93. Lesage F, Guillemare Fink M, Duprat F, Lazdunski M, Romey G, Barhanin J (1996) TWIK-1, a ubiquitous human weakly inward rectifying $\mathrm{K}^{+}$channel with a novel structure. EMBO J 15:1004-1011

94. Levina N, Tötemeyer S, Stokes NR, Louis P, Jones MA, Booth IR (1999) Protection of Escherichia coli cells against extreme turgor pressure by activation of MscS and MscL mechanosensitive channels: identification of genes for MscS activity. EMBO J 18:1730-1737

95. Markin VS, Sachs F (2004) Thermodynamics of mechanosensitivity. Phys Biol 1:110-124

96. Maroto R, Hamill OP (2001) Brefeldin A block of integrindependent mechanosensitive ATP release from Xenopus oocytes reveals a novel mechanism of mechanotransduction. J Biol Chem 276:23867-23872 
97. Maroto R, Raso A, Wood TG, Kurosky A, Martinac B, Hamill OP (2005) TRPC1 forms the stretch-activated cation channel in vertebrate cells. Nature Cell Biol 7:1443-1446

98. Martinac B (2004) Mechanosensitive ion channels: molecules of mechanotransduction. J Cell Sci 117:2449-2460

99. Martinac B (2007) 3.5 billion years of mechanosensory transduction: structure and function of mechanosensitive channels in prokaryotes. In: Hamill OP (ed) Mechanosensitive channels. Elsevier, Amsterdam (in press)

100. Martinac B, Buechner M, Delcour AH, Adler J, Kung C (1987) Pressure-sensitive ion channel in Escherichia coli. Proc Natl Acad Sci USA 84:2297-2301

101. Martinac B, Adler J, Kung C (1990) Mechanosensitive channels of $E$. coli activated by amphipaths. Nature 348:261-263

102. Martinac B, Hamill OP (2002) Gramicidin A channels switch between stretch activation and stretch inactivation depending upon bilayer thickness Proc Natl Acad Sci USA 99: $4308-4312$

103. Martinac B, Kloda A (2003) Evolutionary origins of mechanosensitive ion channels. Prog Biophys Mol Biol 82:11-24

104. Mayer C, Maaser K, Daryab N, Zanker KS Broker EB, Friedl P (2004) Release of cell fragments by invading melanoma cells. Eur J Cell Biol 83:709-715

105. McBride DW Jr, Hamill OP (1999) A simplified fast pressureclamp technique for studying mechanically-gated channels. Methods Enzymol 294:482-489

106. McBride DW Jr, Hamill OP (1995) A fast pressure clamp technique for studying mechano-gated channels. In: Sakmann B, Neher E (eds) Single channel recording, 2nd edn. Plenum, New York, pp 329-340

107. McBride DW Jr, Hamill OP (1992) Pressure-clamp: a method for rapid step perturbation of mechanosensitive channels. Pflugers Arch 421:606-612

108. McBride DW Jr, Hamill OP (1993) Pressure-clamp technique for measurement of the relaxation kinetics of mechanosensitive channels. Trends Neurosci 16:341-345

109. McNeil PL, Steinhardt RA (2003) Plasma membrane disruption: repair, prevention, adaptation. Annu Rev Cell Dev Biol 19: 697-731

110. McNeil PL, Teraski M (2001) Coping with the inevitable: how cells repair a torn surface membrane. Nat Cell Biol 3: E124-E129

111. McNeil PL, Kirchhausen T (2005) An emergency response team for membrane repair. Nat Rev Mol Cell Biol 6:499-505

112. Milton RL, Caldwell JH (1994) Membrane blebbing and tight seal formation: are there hidden artifacts in single channel patch clamp recordings? Comments Theor Biol 3:265-284

113. Moe P, Blount P (2005) Assessment of potential stimuli for mechano-dependent gating of MscL: effects of pressure, tension and lipid headgroups. Biochemistry 44:12239-12244

114. Morris CE (1990) Mechanosensitive ion channels. J Membr Biol 113:93-107

115. Morris CE (2007) Mechanosensitivity of voltage-gated channels. In: Hamill OP (ed) Mechanosensitive channels. Elsevier, Amsterdam (in press)

116. Morris CE, Homann U (2001) Cell surface area regulation and membrane tension. J Membr Biol 179:79-102

117. Morris CE, Horn R (1991) Failure to elicit neuronal macroscopic mechanosensitive currents anticipated by single-channel studies. Science 251:1246-1249

118. Morris CE, Sigurdson WJ (1989) Stretch-inactivated ion channels coexist with stretch-activated channels. Science 243 : 807-809

119. Nichol JA, Hutter OF (1996) Tensile strength and dilatational elasticity of giant sarcolemmal vesicles shed from rabbit muscle. J Physiol 493:187-198
120. O'Hagan R, Chalfie M, Goodman MB (2004) The MEC-4 DEG/ $\mathrm{ENaC}$ channel of Caenorhabditis elegans touch receptor neurons transduces mechanical signals. Nat Neurosci 8:43-50

121. Opsahl LR, Webb WW (1994) Lipid-glass adhesion in gigasealed patch clamped membranes. Biophys J 66:75-79

122. Opsahl LR, Webb WW (1994) Transduction of membrane tension by the ion channel alamethicin. Biophys J 66:71-74

123. Ostrow KL, Sachs F (2005) Mechanosensation and endothelin in astrocytes - hypothetical roles in CNS pathophysiology. Brain Res Brain Res Rev 48:488-508

124. Paoletti P, Ascher P (1994) Mechanosensitivity of NMDA receptors in cultured mouse central neurons. Neuron 13:645-655

125. Patel AJ, Honoré E (2001) Properties and modulation of mammalian $2 \mathrm{P}$ domain $\mathrm{K}^{+}$channels. Trends Neurosci 24: 339-346

126. Patel AJ, Honoré E, Maingret, F, Lesage F, Fink M, Duprat F, Lazdunski M (1998) A mammalian two pore domain mechanogated S-like $\mathrm{K}^{+}$channel. EMBO J 17:4283-4290

127. Patel AJ, Honoré E, Lesage F, Fink M, Romney G, Lazdunski M (1999) Inhalational anesthetics activated two-pore-domain background $\mathrm{K}^{+}$channels. Nat Neurosci 2:422-426

128. Patel AJ, Lazdunski M (2004) The 2P-domain $\mathrm{K}^{+}$channels: role in apoptosis and tumorigenesis. Pflugers Archiv 448:261-273

129. Patel AJ, Lazdunski M, Honoré E (2001) Lipid and mechanogated 2P domain $\mathrm{K}^{+}$channels. Curr Opin Cell Biol 13:422-428

130. Palmer LG (1984) Voltage-dependent block by amiloride and other monovalent cations of apical $\mathrm{Na}$ channels in the toad urinary bladder. J Membr Biol 80:153-165

131. Perozo E (2006) Gating prokaryotic mechanosensitive channels. Nat Rev Mol Cell Biol 7:109-119

132. Perozo E, Kloda A, Cortes DM, Martinac B (2002) Physical principles underlying the transduction of bilayer deformation forces during mechanosensitive channel gating. Nat Struct Biol 9:696-703

133. Perozo E, Rees DC (2003) Structure and mechanism in prokaryotic mechanosensitive channels. Curr Opin Struct Biol $13: 432-442$

134. Prager GW, Binder BR (2004) Genetic determinants: is there an atherosclerosis gene. Acta Med Austriaca 31:1-7

135. Qi Z, Chi S, Su X, Naruse K, Sokabe M (2005) Activation of a mechanosensitive BK channel by membrane stress created with amphipaths. Mol Membr Biol 22:519-527

136. Ramsey IS, Delling M, Clapham DE (2006) An introduction to TRP channels. Annu Rev Physiol 68:619-647

137. Rao JN et al (2006) TRPC1 functions as a store-operated $\mathrm{Ca}^{2+}$ channels in intestinal epithelial cells and regulates early mucosal restitution after wounding. Am J Physiol 290:G782-G792

138. Raucher D, Sheetz MP (1999) Characteristic of a membrane reservoir buffering membrane tension. Biophys J 77:1992-2002

139. Rees DC, Chang G, Spencer RH (2000) Crystallographic analyses of ion channels: lessons and challenges. J Biol Chem 275:713-716

140. Reifarth FW, Clauss W, Weber WM (1999) Stretch-independent activation of the mechanosensitive cation channel in oocytes of Xenopus laevis. Biochim Biophys Acta 1417:63-76

141. Rüsch A, Kros CJ, Richardson GP (1994) Block by amiloride and its derivatives of mechano-electrical transduction in outer hair cells of mouse cochlear cultures. J Physiol 474:75-86

142. Ruknudin A, Song MJ, Sachs F (1991) The ultrastructure of patch-clamped membranes: a study using high voltage electron microscopy. J Cell Biol 112:125-134

143. Sachs F (1988) Mechanical transduction in biological systems. Crit Rev Biomed Eng 16:141-169

144. Sachs F, Morris CE (1988) Mechanosensitive ion channels in nonspecialized cells. Rev Physiol Biochem Pharmacol 132: $1-77$ 
145. Sachs F, Qin F (1993) Gated, ion selective channels observed with patch pipettes in the absence of membranes: novel properties of the giga-seal. Biophys J 65:1101-1107

146. Sackin H (1989) A stretch-activated $\mathrm{K}^{+}$channel sensitive to cell volume. Proc Natl Acad Sci USA 86:1731-1735

147. Sackin H (1995) Mechanosensitive channels. Annu Rev Physiol $57: 333-353$

148. Sheetz MP, Dai J (1996) Modulation of membrane dynamics and cell motility by membrane tension. Trends Cell Biol 6:85-89

149. Sheetz MP, Sable JE, Döbereiner HG (2006) Continuous membrane-cytoskeleton adhesion requires accommodation to lipid and cytoskeleton dynamics. Annu Rev Biophys Biomol Struct 35:417-434

150. Sigurdson WJ, Morris CE (1989) Stretch-activated ion channel in growth cones of snail neurons. J Neurosci 9:2801-2808

151. Small DL, Morris CE (1994) Delayed activation of single mechanosensitive channels in Lymnaea neurons. Am J Physiol 267:C598-C606

152. Sokabe M, Sachs F (1990) The structure and dynamics of patch clamped membrane: a study using differential interference contrast microscopy. J Cell Biol 111:599-606

153. Sokabe M, Sachs F, Jing Z (1991) Quantitative video microscopy of patch clamped membranes - stress, strain, capacitance and stretch channel activation. Biophys J 59:722-728

154. Sokabe M, Nunogaki K, Naruse K, Soga H (1993) Mechanics of patch clamped and intact cell-membranes in relation to SA channel activation (1993) Jpn J Physiol 43:S197-S204

155. Suchyna TM, Johnson JH, Hamer K, Leykam JF, Hage DA, Clemo HF, Baumgarten CM, Sachs F (1998) Identification of a peptide toxin from Grammostola spatula spider venom that blocks cation selective stretch-activated channels. J Gen Physiol 115:583-598

156. Suchyna TM, Besch SR, Sachs F (2004) Dynamic regulation of mechanosensitive channels: capacitance used to monitor patch tension in real time. Phys Biol 1:1-18

157. Suchyna TM, Tape SE, Koeppe RE III, Anderson OS, Sachs F, Gottlieb PA (2004) Bilayer-dependent inhibition of mechanosensitive channels by neuroactive peptide enatiomers. Nature 430:235-240

158. Sukharev S (2002) Purification of the small mechanosensitive channel in Escherichia coli ( $\mathrm{MscS})$ : the subunit structure, conduction and gating characteristics. Biophys J 83:290-298

159. Sukharev SI, Blount P, Martinac B, Blattner FR, Kung C (1994) A large-conductance mechanosensitive channel in E. coli encoded by MscL alone. Nature 368:265-268

160. Sukahrev SI, Martinac B, Arshavsky VY, Kung C (1993) Two types of mechanosensitive channels in the $E$. coli cell envelope: solubilization and functional reconstitution. Biophys J 65:177-183

161. Sukharev SI, Sigurdson WJ, Kung C, Sachs F (1999) Energetic and spatial parameters for gating of the bacterial large conductance mechanosensitive channel, MscL. J Gen Physiol 113:525539

162. Tanaka T, Tamba Y, Masum SM, Yamashita Y, Yamazaki M (2002) $\mathrm{La}^{3+}$ and $\mathrm{Gd}^{3+}$ induced shape change of giant unilamellar vesicles of phosphatidylcholine. Biochim Biophys Acta 1564:173-182

163. Tang QY, Qi Z, Naruse K, Sokabe M (2003) Characterization of a functionally expressed stretch-activated $\mathrm{BKCa}$ channel cloned from chick ventricular myocytes. J Membr Biol 196:185-200

164. Tongo T, Krasieva TB, Steinhardt RA (2000) A decrease in membrane tension precedes successful cell-membrane repair. Mol Biol Cell 11:4339-4346

165. Tousova K, Vyklicky L, Susankova K, Benedikt J, Vlachova V (2004) Gadolinium activates and sensitizes the vanilloid receptor
TRPV1 through the external protonation sites. Mol Cell Neurosci 30:207-217

166. Trebak M, Bird GS, Mckay RR, Putney JW Jr (2002) Comparison of human TRPC3 channels in receptor-activated and store-operated modes. Differential sensitivity to channel blockers suggests fundamental differences in channel composition. J Biol Chem 277:21617-21623

167. Vandebrouck C, Martin D, Colson-Van Schoor M, Debaix H, Gaily P (2002) Involvement of TRPC in the abnormal calcium influx observed in dystrophic $(\mathrm{mdx})$ mouse skeletal muscle fibers. J Cell Biol 158:1089-1096

168. Vandorpe DH, Morris CE (1992) Stretch activation of the Aplysia S-channel. J Membr Biol 127:205-214

169. Vanoye CG, Reuss L (1999) Stretch-activated single $\mathrm{K}^{+}$channels account for whole-cell currents elicited by swelling. Proc Natl Acad Sci USA 96:6511-6516

170. Verkhovsky AB, Svitkina TM, Borisy GG (1999) Self-polarization and directional motility of cytoplasm. Curr Biol 9:11-20

171. Voets T, Talavera K, Owsiannik G, Nilius B (2005) Sensing with TRP channels. Nat Chem Biol 1:85-92

172. Vogel V, Sheetz M (2006) Local force and geometry sensing regulate cell functions. Nat Rev Mol Cell Biol 7:265-275

173. Wan X, Juranka P, Morris CE (1999) Activation of mechanosensitive currents in traumatized membrane. Am J Physiol 276: C318-C327

174. Weber WM, Popp C, Clauss W, van Driessche W (2000) Maitotoxin induces insertion of different ion channels into the Xenopus oocyte plasma membrane via $\mathrm{Ca}^{2+}$-stimulated exocytosis. Pflugers Archiv 439:363-369

175. Welsh DG, Morielli AD, Nelson MT, Brayden JE (2002) Transient receptor potential channels regulate myogenic tone of resistance arteries. Circ Res 90:248-250

176. Wilkinson NS, Gao F, Hamill OP (1998) The effects of blockers of mechanically-gated channels on Xenopus oocyte growth and development. J Membr Biol 165:161-174

177. Wu G, McBride DW Jr, Hamill OP (1998) $\mathrm{Mg}^{2+}$ block and inward rectification of mechanosensitive channels in Xenopus oocytes. Pflugers Archiv 435:572-574

178. Yang XC, Sachs F (1989) Block of stretch-activated ion channels in Xenopus oocytes by gadolinium and calcium ions. Science 243:1068-1071

179. Yang XC, Sachs F (1990) Characterization of stretch-activated ion channels in Xenopus oocytes. J Physiol 431:103-122

180. Yeung EW, Allen DG (2004) Stretch-activated channels in stretch-induced muscle damage: role in muscular dystrophy. Clin Exp Pharmacol Physiol 31:551-556

181. Zampighi GA, Kreman M, Boorer KJ, Loo DDF, Bezanilla F, Chandy G, Hall JE, Wright EM (1995) A method for determining the unitary functional capacity of cloned channels and transporters expressed in Xenopus laevis oocytes. J Membr Biol 148:65-78

182. Zhang Y, McBride DW Jr, Hamill OP (1998) Ion selectivity of a membrane conductance activated by removal of extracellular calcium in Xenopus oocytes. J Physiol 508:763-776

183. Zhang Y, Hamill OP (2000) Calcium, voltage and osmotic stress currents in Xenopus oocytes and their relationship to single mechanically-gated channels. J Physiol 523.1:83-99

184. Zhang Y, Hamill OP (2000) On the discrepancy between membrane patch and whole cell mechanosensitivity in Xenopus oocytes. J Physiol 523.1:101-115

185. Zhang Y, Gao F, Popov V, Wan J, Hamill OP (2000) Mechanicallygated channel activity in cytoskeleton deficient blebs and vesicles from Xenopus oocytes. J Physiol 523.1:117-129 